\title{
Papaver Plants: Current Insights on Phytochemical and Nutritional Composition Along with Biotechnological Applications
}

\author{
Monica Butnariu $\mathbb{D}^{1},{ }^{1}$ Cristina Quispe $\mathbb{D}^{2},{ }^{2}$ Jesús Herrera-Bravo $\mathbb{D}^{\mathrm{D}},{ }^{3,4}$ Marius Pentea $\mathbb{D},{ }^{1}$ \\ Ioan Sarac $\mathbb{D}^{1}{ }^{1}$ Aylin Seylam Küşüimler ${ }^{(D)}{ }^{5}$ Beraat Özçelik $\left(\mathbb{D},{ }^{6,7}\right.$ Sakshi Painuli, \\ Prabhakar Semwal $\mathbb{D}^{8,10}$ Muhammad Imran, ${ }^{11}$ Tanweer Aslam Gondal, ${ }^{12}$ \\ Simin Emamzadeh-Yazdi, ${ }^{13}$ Natallia Lapava ${ }^{(D)},{ }^{14}$ Zubaida Yousaf, ${ }^{15}$ Manoj Kumar $\mathbb{D}^{16}$ \\ Ali Hussein Eid, ${ }^{17,18}$ Yusra Al-Dhaheri, ${ }^{19}$ Hafiz Ansar Rasul Suleria $\mathbb{D}^{20},{ }^{20}$ \\ María del Mar Contreras $\left(\mathbb{D},{ }^{21}\right.$ Javad Sharifi-Rad $\left(\mathbb{D},{ }^{22}\right.$ and William C. Cho $\mathbb{D}^{23}$ \\ ${ }^{1}$ Banat's University of Agricultural Sciences and Veterinary Medicine "King Michael I of Romania" from Timisoara, \\ Timisoara, Romania \\ ${ }^{2}$ Facultad de Ciencias de la Salud, Universidad Arturo Prat, Avda. Arturo Prat 2120, Iquique 1110939, Chile \\ ${ }^{3}$ Departamento de Ciencias Básicas, Facultad de Ciencias, Universidad Santo Tomas, Chile \\ ${ }^{4}$ Center of Molecular Biology and Pharmacogenetics, Scientific and Technological Bioresource Nucleus, Universidad de La Frontera, \\ Teтuco 4811230, Chile \\ ${ }^{5}$ İstanbul Okan University, Nutrition and Dietetics Department, Tuzla, İstanbul, Turkey \\ ${ }^{6}$ Department Food Engineering, Faculty of Chemical and Metallurgical Engineering, Istanbul Technical University, Maslak, \\ 34469 Istanbul, Turkey \\ ${ }^{7}$ BIOACTIVE Research \& Innovation Food Manufacturing Industry Trade LTD Co., Maslak, Istanbul 34469, Turkey \\ ${ }^{8}$ Department of Biotechnology, Graphic Era University, 248001, Dehradun, Uttarakhand, India \\ ${ }^{9}$ Himalayan Environmental Studies and Conservation Organization, Prem Nagar, Dehradun, 248001 Uttarakhand, India \\ ${ }^{10}$ Department of Life Sciences, Graphic Era Deemed to be University, Dehradun-248002, Uttarakhand, India \\ ${ }^{11}$ University Institute of Diet and Nutritional Sciences, Faculty of Allied Health Sciences, The University of Lahore-Lahore, Pakistan \\ ${ }^{12}$ School of Exercise and Nutrition, Deakin University, Victoria 3125, Australia \\ ${ }^{13}$ Department of Plant and Soil Sciences, University of Pretoria, Gauteng 0002, South Africa \\ ${ }^{14}$ Medicine Standardization Department of Vitebsk State Medical University, Belarus \\ ${ }^{15}$ Department of Botany, Jail Road, Lahore 54000, Pakistan \\ ${ }^{16}$ Chemical and Biochemical Processing Division, ICAR-Central Institute for Research on Cotton Technology, 400019, \\ Mumbai, India \\ ${ }^{17}$ Department of Basic Medical Sciences, College of Medicine, QU Health, Qatar University, PO Box 2713, Doha, Qatar \\ ${ }^{18}$ Biomedical and Pharmaceutical Research Unit, QU Health, Qatar University, PO Box 2713, Doha, Qatar \\ ${ }^{19}$ Department of Biology, College of Science, United Arab Emirates University, UAE \\ ${ }^{20}$ Department of Agriculture and Food Systems, The University of Melbourne, Melbourne 3010, Australia \\ ${ }^{21}$ Department of Chemical, Environmental and Materials Engineering, Universidad de Jaén, Campus las Lagunillas, s/n, \\ 23071 Jaén, Spain \\ ${ }^{22}$ Facultad de Medicina, Universidad del Azuay, Cuenca, Ecuador \\ ${ }^{23}$ Department of Clinical Oncology, Queen Elizabeth Hospital, Kowloon, Hong Kong
}

Correspondence should be addressed to Prabhakar Semwal; semwal.prabahakar@gmail.com, María del Mar Contreras; mar.contreras.gamez@gmail.com, Javad Sharifi-Rad; javad.sharifirad@gmail.com, and William C. Cho; chocs@ha.org.hk

Received 19 May 2021; Revised 13 July 2021; Accepted 6 January 2022; Published 3 February 2022

Academic Editor: Tarique Hussain 
Copyright (C) 2022 Monica Butnariu et al. This is an open access article distributed under the Creative Commons Attribution License, which permits unrestricted use, distribution, and reproduction in any medium, provided the original work is properly cited. The publication of this article was funded by Qatar National Library.

\begin{abstract}
The genus Papaver is highly esteemed in the pharmacy industry, in the culinary field, and as ornamental plants. These plants are also valued in traditional medicine. Among all Papaver species, Papaver somniferum L. (opium poppy) is the most important species in supplying phytochemicals for the formulation of drugs, mainly alkaloids like morphine, codeine, rhoeadine, thebaine, and papaverine. In addition, Papaver plants present other types of phytochemicals, which altogether are responsible for its biological activities. Therefore, this review covers the phytochemical composition of Papaver plants, including alkaloids, phenolic compounds, and essential oils. The traditional uses are reviewed along with their pharmacological activities. Moreover, safety aspects are reported to provide a deep overview of the pharmacology potential of this genus. An updated search was carried out in databases such as Google Scholar, ScienceDirect, and PubMed to retrieve the information. Overall, this genus is a rich source of alkaloids of different types and also contains interesting phenolic compounds, such as anthocyanins, flavonols, and the characteristic indole derivatives nudicaulins. Among other pharmacological properties, numerous preclinical studies have been published about the analgesic, anticancer, antimicrobial, antioxidant, and antidiabetic activities of Papaver plants. Although it highlights the significant impact of this genus for the treatment of a variety of diseases and conditions, as a future prospect, characterization works accompanying preclinical studies are required along with clinical and toxicology studies to establish a correlation between the scientific and traditional knowledge.
\end{abstract}

\section{Introduction}

Many plants are naturally rich sources of phytochemicals with valuable biological properties, which could have significant impact for the treatment of a variety of diseases and conditions and as potential alternative options for synthetic drugs. This is also the case of the genus Papaver (family Papaveraceae), which is known for its medicinal properties attributed to their phytochemical composition ([1]; [180].

This genus belongs to the family Papaveraceae, which is a cosmopolitan family growing from tropical to alpine ecosystems [1], mainly in the northern hemisphere [2]. The flowers have no style, but on the top of the ovary, a stigmatic tissue is arranged radially on a sessile stigmatic disc. Their similar characteristics in their flower shapes, colors, and fruits complicate the identification based only on morphological characteristics [2], and different number of species is given in literature. For example, it consists of $\sim 80$ 100 species, including annual, biennial, and perennial herbs $[1,3]$. As the family, the genus Papaver is widely natural distributed, especially in regions with Mediterranean climate $[1,4]$. In the case of Papaver somniferum L. (opium poppy), the most important species and due to its narcotic properties, it is highly produced in countries such as Afghanistan, Myanmar, Mexico, and Lao PDR (or Laos) [5], but illegally [6]. Alternatively, Turkey is one of the main legal manufacturers of the poppy plant [7], along with Czechia, Spain, etc. Figure 1 shows the world production of poppy seeds in the last twenty years according to the data available from the Food and Agriculture Organization of the United Nations [8].

Other commonly cultivated species of the genus Papaver are Papaver bracteatum Lindl. (Iranian poppy), Papaver rhoeas L. (common poppy or corn poppy), Papaver dubium L., Papaver pseudo-orientale Medw., and Papaver orientale L. $P$. bracteatum that grow wild in high altitudes in north and northwest of Iran, in Russia and Caucasia regions [9]. $P$. rhoeas is an important competitive plant in winter cereals in southern Europe under Mediterranean climate [10] and thus called corn poppy. P. dubium is also called long-head poppy. P. dubium is widespread throughout Europe and America and is an important weed in western Iran [11]. $P$. orientale and $P$. pseudo-orientale are distributed into the Caucasus area [12].

Concerning the natural product field, P. somniferum was the first source of natural drugs with the obtainment of analgesic morphine drugs [13], including codeine, morphine, and a variety of semisynthetic derivatives, mainly derived from thebaine, such as oxycodone and buprenorphine [14]. These compounds belong to the opiate family that has analgesic properties mainly by binding to the mu-opioid receptor within the central nervous system (CNS) and the peripheral nervous system. It leads to an overall reduction of the nociceptive transmission [15]. However, the latex of the opium poppy is not only used for the treatment of severe pain, but it is also subjected to opioid abuse and drug trafficking due to the narcotic properties of these compounds. Therefore, their production is regulated internationally.

$P$. bracteatum has high content of thebaine as the main alkaloid, which has been utilized in the production of codeine [16]. Besides these compounds, the nonnarcotic papaverine is another economically important alkaloid with vasodilator properties $[1,17]$.

Apart from the alkaloids, poppy plant is a rich source of phenolic compounds, such as anthocyanins, flavonols, and the characteristic indole derivatives nudicaulins, and essential oil volatiles, which altogether are responsible for its pharmacological activities.

Moreover, Papaver seeds are esteemed in the food sector, e.g., to be used in bakery and desserts and to produce oil. For example, P. somniferum seeds are used in some Central Eastern European countries (European Food Safety Authority, [18]). In this context, poppy can be classified into three main categories depending on the use: industrial poppy intended for alkaloid extraction from the capsule of the plant; culinary poppy when it is grown to obtain seeds and oil; both industrial and culinary poppy [19]. P. rhoeas is also used as garniture in salad in some regions [20], and the seeds of $P$. bracteatum are used in foods in Central Anatolia [21]. 


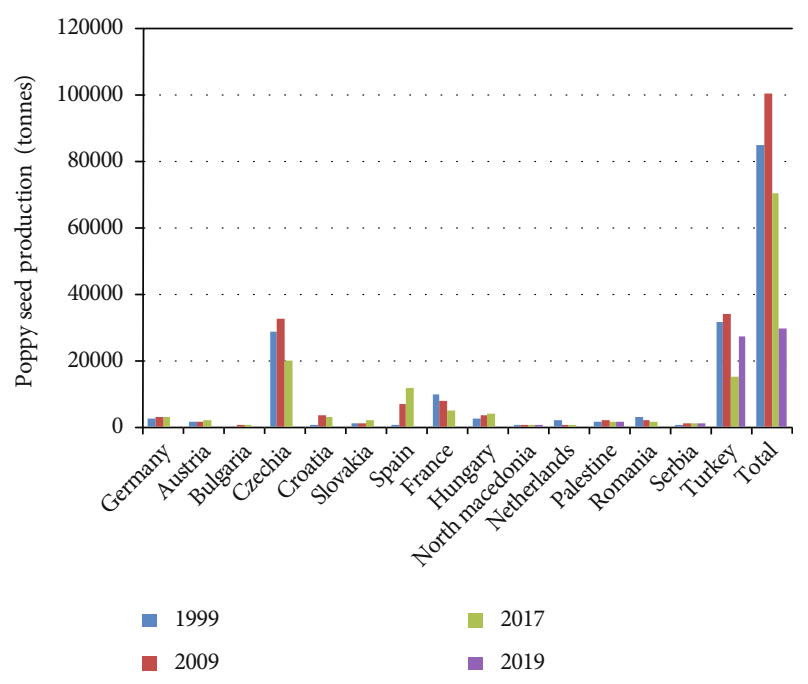

Figure 1: World production of poppy seeds in 1999, 2009, 2017, and 2019 according to FAOSTAT [8].

Other different use is as ornamental plants like $P$. orientale and P. pseudo-orientale [2].

Moreover, besides the aforementioned applications for the main important alkaloids, the bioactive properties of the genus Papaver are wide. Antioxidant, antimicrobial, anticancer, anti-inflammation, neuroprotection, and maintenance of fertility are some of the important bioactivities of the Papaver genus plant extracts, as depicted in the following. In this context, this review describes the traditional uses of Papaver species, their phytochemical composition, and bioactive properties, describing preclinical and clinical studies. Moreover, safety aspects are well discussed with important case studies. The overall components and pharmacological activities of the review are well illustrated in Figure S1.

\section{Databases, e-Resources, and Keyword Search}

Various search engines for the survey of the literature were used to compile the scientific information included in the current review. In particular, Google Scholar, ScienceDirect, PubMed, and SpringerLink were used. Literature was retrieved from the books and international journals of highly cited publishers, including Elsevier, Springer, Frontiers, Wiley, and Taylor and Francis. Very few information was derived from national journals with no information of the ranking on the basis of citations. The keywords "Papaver", "Papaver somniferum", "opium poppy", "opium", "traditional uses", "ethnopharmacology", "bioactivities", "biological activities", "phytochemical profile", and combinations of these words were used for deriving the particular information about the Papaver genus. Any article in the English language mentioning these keywords was included in the review article. The research articles, which were exclusively related to the agronomic traits of the Papaver genus, were excluded for compiling the information of the current review. Moreover, ChemBioDraw Ultra 12.0 (CambridgeSoft, Cambridge, MA, USA) was used to draw the chemical structures of the phytochemical compounds from the Papaver genus.

\section{Ethnobotanical Uses of the Papaver Genus in Different Human Cultures}

The traditional and medicinal properties of this genus have been documented since $3000 \mathrm{BC}$. The main analgesic compound "morphine" was isolated from P. somniferum L. by a German pharmacist "Sertüner" in 1905 [22]. The genus Papaver is not popular for traditional medicine due to narcotic and other side effects. Nevertheless, there are several uses such as anti-inflammatory, antidiabetic, analgesic, and remedy for cough and lung infection as described in traditional medicine and detailed in Table 1 . This includes the use of the flowers, buds, seeds, fruits, and leaves or aerial parts of the most popular species of Papaver in different countries and cultures.

\section{Phytoconstituents}

The identification of the phytochemical composition of medicinal plants is highly important to provide a best known of the active compounds. It involves complex mixtures of natural compounds with different organic structures and varies depending on the plant source [48].

Papaver species contain alkaloids, phenolic compounds, and essential oil volatiles, among other components [49]. These classes found in different parts of the Papaver plants are discussed in the following subsections.

4.1. Alkaloids. As other phytochemicals, the production of alkaloids in poppy plants is induced by environmental stress conditions, but the details about regulatory processes are not well known and subjected of ongoing studies [50]. Moreover, the alkaloid composition varies even within the same species [51]. This makes that the Papaver genus yields more than 170 alkaloids $[52,53]$. As an example, Figure 2 summarizes the type of alkaloids found in the genus Papaver with their chemical structures.

In particular, $P$. somniferum presents interesting benzylisoquinoline alkaloids, such as papaverine, and the morphinanes morphine, codeine, and thebaine (Table 2, Figure 2), as mentioned in Section 1. Since P. somniferum has been extensively utilized illegally, its cultivation is strictly regulated by the International Narcotics Control Board [54, 55]. The latex of the opium poppy, which surrounds the seed capsule [56], may contain up to 80 alkaloids, but the latter compounds, morphine, codeine, and thebaine, along with narcotine and narceine are generally the main alkaloids $[17,18]$.

P. bracteatum is also a source of the alkaloid thebaine, the precursor of the opiate analgesics codeine, buprenorphine, oxymorphone, and oxycodone $[14,57,58]$. The plant capsule of this species shows high concentrations of morphine and oripavine (another morphinan) as compared to the stem tissues. It seems that the origin and even the latitude affect the thebaine, morphine, and oripavine [59]. This makes that it has intraspecies variation. For example, another study found that the major alkaloids in this species were salutaridine (promorphinan) and thebaine [53]. 
Table 1: Traditional medical usage of Papaver species.

\begin{tabular}{|c|c|c|c|}
\hline Papaver species & Country & Internal/external usage & References \\
\hline P. argemone $\mathrm{L}$. & Iran & Flower (headache, coughs) & Naghibi et al. [23] \\
\hline P. bracteatum Lindl. & Iran & $\begin{array}{c}\text { Flowers, leaves, seeds (hypnotic and sedative, respiratory } \\
\text { tract infections, sore throat, food digestion, eyelid } \\
\text { inflammation, spasm, rheumatism pains) }\end{array}$ & Farouji and Khodayari [24] \\
\hline P. dubium L. & Turkey & Flower (colds, cough) & $\begin{array}{l}\text { Altundaga and Ozturkb [25]; } \\
\text { Çakılcıŏlu et al. [26] }\end{array}$ \\
\hline P. lacerum Popov & Turkey & Buds (goiter) & Altundaga and Ozturkb [25] \\
\hline P. lateritium K. Koch & Turkey & Flower (sedative, antitussive, bronchial, hypnotic) & Akbulut and Bayramoglu [27] \\
\hline $\begin{array}{l}\text { P. macrostomum } \\
\text { Boiss. \& A.Huet }\end{array}$ & Turkey & Flower (cough) & Altundaga and Ozturkb [25] \\
\hline P. orientale $\mathrm{L}$. & Turkey & Seed (laxative); leaf (asthma) & Altundaga \& Ozturkb [25] \\
\hline \multirow{6}{*}{ P. rhoeas L. } & Turkey & $\begin{array}{l}\text { Herb (sedative); fruit, seed (gastrointestinal diseases) } \\
\text { External usage: aerial part (red spots on body); } \\
\text { fruit (burns); seed (dermal diseases, wound) }\end{array}$ & $\begin{array}{l}\text { Altundaga and Ozturkb [25]; } \\
\text { Çakılcığlu et al. [26]; Polat and } \\
\text { Satıl [28]; Ugulu [29]; } \\
\text { Yipel et al. [30] }\end{array}$ \\
\hline & Italy & $\begin{array}{l}\text { Fruit, young shoot (sedative, hypnotic); young } \\
\text { aerial part (depurative); leaf, flower (mental-nervous, } \\
\text { hypnotic, mild sedative for child, cough) }\end{array}$ & $\begin{array}{c}\text { González-Tejero et al. [31]; } \\
\text { Mattalia et al. [32]; Naghibi et al. } \\
\text { [23]; Pieroni, [33]; } \\
\text { Pieroni and Quave [34]; } \\
\text { Scherrer et al. [35]; } \\
\text { Vitalin et al. [36]; }\end{array}$ \\
\hline & Algeria & Aerial part (respiratory diseases) & Gonzalez-Tejero et al. [31] \\
\hline & Cyprus & Aerial part (nervous/mental conditions, digestive) & Gonzalez-Tejero et al. [31] \\
\hline & Spain & Aerial part (respiratory diseases) & Gonzalez-Tejero et al. [31] \\
\hline & Iran & Seed, capsule (antidiabetic); flower (addiction, sedative, hypnotic) & $\begin{array}{c}\text { Bahmani et al. [37]; } \\
\text { Nadaf et al. [38] }\end{array}$ \\
\hline \multirow{5}{*}{ P. somniferum $\mathrm{L}$. } & Turkey & Fruit, seed (gastrointestinal, nervous and respiratory diseases) & Yipel et al. [30] \\
\hline & Italy & Fruit, seed (tranquiliser, toothaches) & Pieroni and Quave [34] \\
\hline & India & $\begin{array}{c}\text { Seed (demulcent, spasmolytic, muscle catch, tonic); } \\
\text { fruit (cough, diarrhea) } \\
\text { External usage: leaf (swelling) }\end{array}$ & $\begin{array}{l}\text { Jadnav [39]; Dar et al. [40]; } \\
\text { Goyal [41]; Tayade } \\
\text { and Patil [42] }\end{array}$ \\
\hline & Pakistan & $\begin{array}{l}\text { Herb (narcotic, stimulant, to increase performance, cough } \\
\text { suppressant); fruit, leaf (analgesic, narcotics); seed (narcotic, } \\
\text { analgesic, sedative, increases excitement and physical vigor) }\end{array}$ & $\begin{array}{l}\text { Adnan et al., [43]; } \\
\text { Alamgeer et al. [44]; } \\
\text { Irfan et al. [45]; } \\
\text { Ullah et al. [46] }\end{array}$ \\
\hline & Korea & External usage: fruit, latex, stem (furuncle) & Kim and Song [47] \\
\hline
\end{tabular}

Concerning $P$. rhoeas, phytochemical composition has showed rhoeadine alkaloids as major compounds, including rhoeadine and rhoeagenine $[60,61]$. Recent trends based on mass spectrometry (MS) analysis enabled the identification of a high number of phytochemicals from Papaver samples. For alkaloid profiling, electrospray ionization in the positive ionization modes generally leads to richer and complex chromatographic profiles with more intense signals for elucidation purposes [62]. Using this technique, for example, 55 alkaloids were characterized in the aerial parts of $P$. rhoeas and $P$. somniferum. This included benzophenanthridine, protoberberine, benzylisoquinoline, aporphine, and rhoeadine-type alkaloids (see examples, in Figure 2). The most characteristic feature was that rhoeadine alkaloids were observed only in P. rhoeas samples, and codeine and morphine were tentatively identified in $P$. somniferum [180] (Table 2).
In the latter work, different solvents were tested for extraction including ethyl ether with 10\% ammonia, pure ethanol, and methanol, as well as aqueous-methanol $50 \%$ and $80 \%$. Among them, ethanol can be applied to extract the aerial parts of $P$. rhoeas and $P$. somniferum, with advantages due to its high extraction efficiency [181] and as its low toxicity. Similarly, four Papaver species (Papaver Lacerum Popov, Papaver syriacum Boiss. \& Blanche, Papaver glaucum Boiss. \& Hausskn., and P. rhoeas) were collected from different sites in Turkey and the aerial parts were extracted using methanol. By using LC-tandem MS, two alkaloids, pronuciferine (proaporphine type) and roemerine (aporphine type), were determined in the selected species [63]. The latter compound was the major one in some $P$. rhoeas samples [64]. Recent studies showed that both alkaloids increase brainderived neurotrophic factor (BDNF) protein expression in hippocampal SH-SY5Y cells demonstrating that besides the 


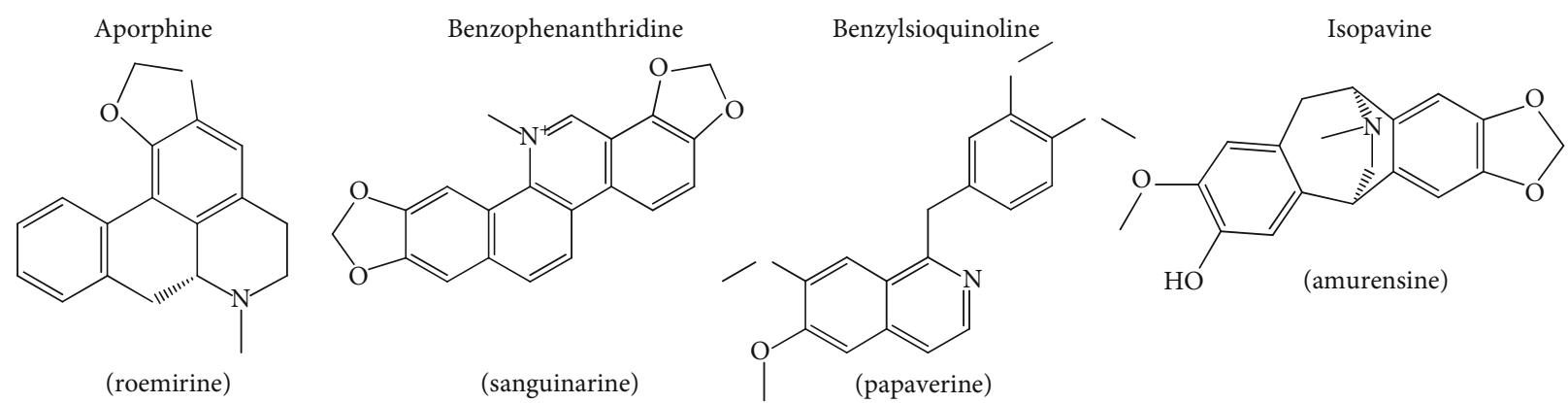

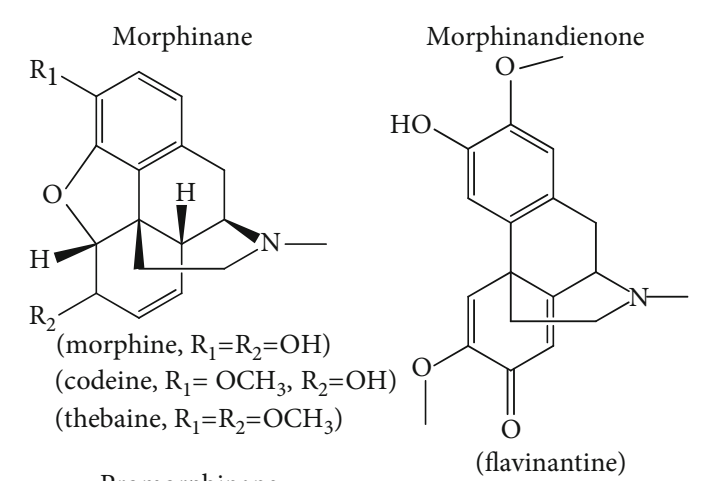

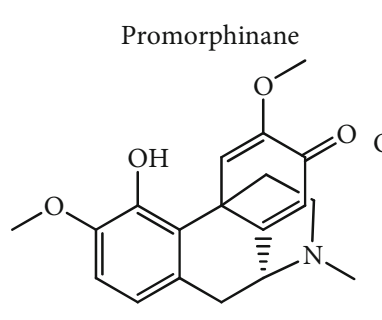

(salutaridine)<smiles>COc1cc2c(c(CO)c1OC)C[C@@H]1c3c(cc4c(c3OC)OCO4)CCN1C2</smiles>

(mecambridine)

Tetrahydroisoquinoline<smiles>COc1ccc(CC2c3cc(OC)c(OC)cc3CCN2C)cc1OC</smiles>

(laudanosine)<smiles>COc1ccc2c([C@@H](N(C)C)[C@@]3(C)CC(=O)c4c(OC)cccc43)c1OCO2</smiles><smiles>CCCCC1CN(C)C2CC3(C=CC(=O)C=C3)c3c(OC)c(OC)cc1c32</smiles>

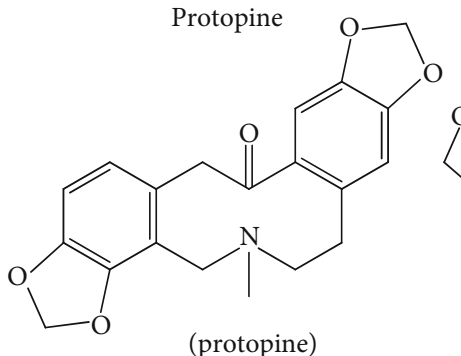<smiles></smiles>

(rhoeadine)<smiles>COc1cc2c(cc1O)[C@H]1Cc3ccc(OC)c(OC)c3CN1CC2</smiles>

FIgUre 2: Selected alkaloids to exemplify the chemical structure of the different types found in the genus Papaver.

common poppy alkaloids, the former alkaloids could also be interesting [65]. Other compounds identified were salutaridine (promorphinan type), coulteropine (protopine type), and rhoeadine derivatives (epiglaucamine, glaudine, and rhoeagenine) [64]. Furthermore, using a combination of LC-MS and molecular networking, isoquinoline alkaloids in Papaver nudicaule L. and P. rhoeas aerial parts were clustered. 42 and 16 compounds were characterized, respectively, and a variation was observed depending on the color of the flowers [66].

P. macrostomum, which is widely distributed in Turkey, contains alkaloids such as protopine (protopine), benzylisoquinoline (macrostomine, dehydromacrostomine, sevanine), rhoeadine (rhoeadine, papaverrubine A-E), aporphine (iso- corydine), isopavine (amurensine, amurensinine), protoberberine (cheilantifoline), proaporphine (mecambrine), and benzyl tetrahydroisoquinoline (laudanosine) types [67]. Moreover, the major alkaloids of $P$. orientale were oripavine (morphinan type) and mecambridine (protoberberine type) and of $P$. pseudo-orientale were also mecambridine and isothebaine (aporphine type) and orientalidine (protoberberine type). Main compounds of Papaver duvium L. are berberine and thalifendine, while roemerine is present in P. lacerum. The presence of isocorydine, stylopine (tetrahydroprotoberberine type) and tetrahydropseudocoptisine, roemerine, mecambrine, and allocryptopine depends on the subspecies [68]. The alkaloid composition of other less known Papaver species was described by Sariyar [53]. 
Table 2: Alkaloids characterized in Papaver rhoeas L. and Papaver somniferum L. by mass spectrometry in different locations. Adapted from [181].

\begin{tabular}{|c|c|c|c|c|c|c|c|}
\hline Name & Formula & Mass $(\mathrm{Da})$ & MS/MS fragments $(m / z)$ & Alkaloid type & PR (R) & PR (SK) & PS \\
\hline DL-Demethylcoclaurine* & $\mathrm{C}_{16} \mathrm{H}_{17} \mathrm{NO}_{3}$ & 271.12 & $107.05,255.10,161.06,143.05$ & Benzylsioquinoline & + & + & + \\
\hline Coclaurine* & $\mathrm{C}_{17} \mathrm{H}_{19} \mathrm{NO}_{3}$ & 285.14 & $107.05,269.12,175.07,237.09$ & Benzylsioquinoline & + & + & + \\
\hline Tetrahydropapaverine* & $\mathrm{C}_{20} \mathrm{H}_{25} \mathrm{NO}_{4}$ & 343.18 & $192.10,189.09,151.08,327.16$ & Benzylsioquinoline & - & - & + \\
\hline Reticuline* & $\mathrm{C}_{19} \mathrm{H}_{23} \mathrm{NO}_{4}$ & 329.16 & $192.10,137.06,143.05,175.07$ & Benzylsioquinoline & + & + & + \\
\hline Corytuberine* & $\mathrm{C}_{19} \mathrm{H}_{21} \mathrm{NO}_{4}$ & 327.15 & $265.09,237.09,297.11,205.06$ & Aporphine & + & + & + \\
\hline Tetrahydrocolumbamine* & $\mathrm{C}_{20} \mathrm{H}_{23} \mathrm{NO}_{4}$ & 341.16 & $178.09,163.06,176.07$ & $\begin{array}{l}\text { Protoberberine } \\
\text { (THPB) }\end{array}$ & - & - & + \\
\hline Scoulerine* & $\mathrm{C}_{19} \mathrm{H}_{21} \mathrm{NO}_{4}$ & 327.15 & $237.09,207.04,211.08,239.07$ & $\begin{array}{l}\text { Protoberberine } \\
\text { (THPB) }\end{array}$ & - & - & + \\
\hline L-Tetrahydropalmatine* & $\mathrm{C}_{21} \mathrm{H}_{25} \mathrm{NO}_{4}$ & 355.18 & $192.10,165.09,176.07$ & $\begin{array}{l}\text { Protoberberine } \\
\text { (THPB) }\end{array}$ & + & - & + \\
\hline Tetrahydroberberine (canadine)* & $\mathrm{C}_{20} \mathrm{H}_{21} \mathrm{NO}_{4}$ & 339.15 & $176.07,149.06,174.05$ & $\begin{array}{l}\text { Protoberberine } \\
\text { (THPB) }\end{array}$ & + & - & + \\
\hline Berberine* $^{*}$ & $\mathrm{C}_{20} \mathrm{H}_{18} \mathrm{NO}_{4}$ & 336.12 & $\begin{array}{c}320.09,292.10,321.10 \\
306.08,278.08\end{array}$ & Protoberberine & + & + & + \\
\hline Stylopine* & $\mathrm{C}_{19} \mathrm{H}_{17} \mathrm{NO}_{4}$ & 323.12 & $176.07,149.06$ & $\begin{array}{l}\text { Protoberberine } \\
\quad \text { (THPB) }\end{array}$ & + & + & + \\
\hline Dihydrosanguinarine* & $\mathrm{C}_{20} \mathrm{H}_{15} \mathrm{NO}_{4}$ & 333.10 & $318.08,319.08,304.10,276.10$ & Benzophenanthridine & + & + & + \\
\hline Sanguinarine & $\mathrm{C}_{20} \mathrm{H}_{14} \mathrm{NO}_{4}$ & 332.09 & $317.07,274.09,304.10$ & Benzophenanthridine & + & - & - \\
\hline Protopine ${ }^{*}$ & $\mathrm{C}_{20} \mathrm{H}_{19} \mathrm{NO}_{5}$ & 353.13 & $188.07,189.08,149.06$ & Protopine & + & + & + \\
\hline Allocryptopine* & $\mathrm{C}_{21} \mathrm{H}_{23} \mathrm{NO}_{5}$ & 369.16 & $188.07,189.08,290.09$ & Protopine & + & - & - \\
\hline Morphine & $\mathrm{C}_{17} \mathrm{H}_{19} \mathrm{NO}_{3}$ & 285.14 & $201.09,229.08,185.06,211.07$ & Morphinan & - & - & + \\
\hline Mecambrine & $\mathrm{C}_{18} \mathrm{H}_{17} \mathrm{NO}_{3}$ & 295.12 & $202.09,171.07,280.10$ & Proaporphine & - & - & + \\
\hline Codeine & $\mathrm{C}_{18} \mathrm{H}_{21} \mathrm{NO}_{3}$ & 299.15 & $215.11,243.10,225.09,199.07$ & Morphinan & - & - & + \\
\hline (S)-N-Methylcoclaurine & $\mathrm{C}_{18} \mathrm{H}_{21} \mathrm{NO}_{3}$ & 299.15 & $269.12,107.05,271.13$ & Benzylisoquinoline & + & + & + \\
\hline Armepavine & $\mathrm{C}_{19} \mathrm{H}_{23} \mathrm{NO}_{3}$ & 313.17 & $\begin{array}{c}107.05,58.07,269.12 \\
271.13,298.11\end{array}$ & Benzylisoquinoline & + & + & + \\
\hline $\begin{array}{l}\text { (S)-3'-Hydroxy-N } \\
\text {-methylcoclaurine }\end{array}$ & $\mathrm{C}_{18} \mathrm{H}_{21} \mathrm{NO}_{4}$ & 315.15 & $192.10,123.04,285.11,300.12$ & Benzylisoquinoline & + & + & + \\
\hline (S)-Cheilanthifoline & $\mathrm{C}_{19} \mathrm{H}_{19} \mathrm{NO}_{4}$ & 325.13 & $178.09,190.09,163.06$ & Protoberberine & + & + & + \\
\hline Papaverine & $\mathrm{C}_{20} \mathrm{H}_{21} \mathrm{NO}_{4}$ & 339.15 & $202.09,324.12,296.13,171.07$ & Benzylisoquinoline & - & - & + \\
\hline Cryptopine & $\mathrm{C}_{21} \mathrm{H}_{23} \mathrm{NO}_{5}$ & 369.16 & $352.12,205.11,165.09,190.09$ & Protopine & + & + & + \\
\hline Noscapine & $\mathrm{C}_{22} \mathrm{H}_{23} \mathrm{NO}_{7}$ & 413.15 & $220.10,353.10,365.10,179.07$ & $\begin{array}{l}\text { Phthalide } \\
\text { isoquinoline }\end{array}$ & + & - & + \\
\hline Codeinone & $\mathrm{C}_{18} \mathrm{H}_{19} \mathrm{NO}_{3}$ & 297.14 & $283.12,282.11,254.12,266.12$ & Morphinan & + & - & - \\
\hline Morphine $N$-oxide & $\mathrm{C}_{17} \mathrm{H}_{19} \mathrm{NO}_{4}$ & 301.13 & $284.13,241.09$ & Morphinan & - & - & + \\
\hline Flavinantine & $\mathrm{C}_{19} \mathrm{H}_{21} \mathrm{NO}_{4}$ & 327.15 & $178.09,163.06$ & Morphinandienone & - & - & + \\
\hline $\begin{array}{l}\text { 8,14-Dihydroflavinantine } \\
\text { (or salutaridinol) }\end{array}$ & $\mathrm{C}_{19} \mathrm{H}_{23} \mathrm{NO}_{4}$ & 329.16 & $285.11,123.04,58.07,143.05$ & Morphinan & + & + & + \\
\hline (S)-cis-N-Methylstylopine & $\mathrm{C}_{20} \mathrm{H}_{20} \mathrm{NO}_{4}$ & 338.14 & $191.09,190.09,149.06$ & Protoberberine & + & + & - \\
\hline Isocorydine & $\mathrm{C}_{20} \mathrm{H}_{23} \mathrm{NO}_{4}$ & 341.16 & $297.11,265.09,237.09$ & Aporphine & + & + & + \\
\hline Pseudoprotopine & $\mathrm{C}_{20} \mathrm{H}_{19} \mathrm{NO}_{5}$ & 353.13 & $188.07,189.08,149.06$ & Protopine & + & + & - \\
\hline $\begin{array}{l}\text { Amurensinine } N \text {-oxide A } \\
\text { (or amurensinine } N \text {-oxide B) }\end{array}$ & $\mathrm{C}_{20} \mathrm{H}_{21} \mathrm{NO}_{5}$ & 355.14 & $190.06,191.09,277.09,151.08$ & Isopavine & + & + & + \\
\hline Rheagenine (or isorheagenine) & $\mathrm{C}_{20} \mathrm{H}_{19} \mathrm{NO}_{6}$ & 369.12 & $352.12,340.13,324.12$ & Rhoeadine & + & + & - \\
\hline Rhoeadine (or isorhoeadine) & $\mathrm{C}_{21} \mathrm{H}_{21} \mathrm{NO}_{6}$ & 383.14 & $321.08,303.06,291.07,366.13$ & Rhoeadine & + & + & - \\
\hline Glaucamine (or isoglaucamine) & $\mathrm{C}_{21} \mathrm{H}_{23} \mathrm{NO}_{6}$ & 385.15 & $368.15,338.10$ & Rhoeadine & + & + & - \\
\hline Coptisine & $\mathrm{C}_{19} \mathrm{H}_{14} \mathrm{NO}_{4}$ & 320.09 & $\begin{array}{c}292.10,277.07,290.08 \\
318.08,262.09\end{array}$ & Protoberberine & + & + & + \\
\hline
\end{tabular}

PR: Papaver rhoeas; PS: Papaver somniferum; THPB: tetrahydroprotoberberine; RS: Russia; SK: South Korea; * univocally identified through comparison with standards. 
Rhoeadine is another group of alkaloids which is very common and widespread in the genus Papaver and contains at least 25 types. Particularly, alpinigenine, alpinine, and epialpinine were isolated from the Papaver alpinum L., whereas epiglaudine was isolated from the P. glaucum. Other rhoeadine-type alkaloids include glaucamine, glaudine, isorhoeadine, isorhoeagenine, isorhoeagenine-D-glucoside, $\mathrm{N}$ methylporphyroxigenine, oreodine, oreogenine, papaverrubines A, B, C, D, E, F, G, H, rhoeadine, and rhoeagenine which are extracted from different species of Papaver. In general, all rhoeadines are characterized by a benzazepine system fused with six-membered acetal or hemiacetal moieties [69].

4.2. Phenolic Compounds. Phenolic compounds are natural antioxidants and other interesting phytochemicals found in Papaver plants. For example, petals of $P$. rhoeas flowers present flavonoids, which are responsible for their color, including white, yellow orange, white, and red colors. Particularly, the red flowers of this species contain anthocyanins [70]. This agreed with the results obtained by Soulimani et al. [71], who showed that a lyophilized ethanolic aqueous extract of $P$. rhoeas petals has anthocyanins, whereas no alkaloids were detected. Anthocyanins such as pelargonidin glycosides have been detected in red and orange petals of the plant [72].

In $P$. nudicaule cultivars, the flavonoid-derived indole alkaloids, nudicaulins, along with pelargonidin glycosides (anthocyanin), and kaempferol and gossypetin glycosides (flavonols) have been reported in the apical petals (Figure 3) [73, 74]. Other flavonoids such as gossypetin glycosides are present in the basal spot of all cultivars whereas carotenoids are present in yellow-colored stamens [73]. Another study found nudicaulins, gossypetin 7-O-glucoside (gossypitrin), and seven kaempferol glycosides in yellow petals of this plant [75]. Moreover, Papaver alpinum L. also accommodates some of these compounds [74].

Among the solvents, water, ethanol, and aqueous ethanol can be applied to extract high amounts of phenolics, but among them, the water extract showed the highest phenolic content. It was found that the aqueous extract of $P$. somniferum stalk contains high amount of phenolics, including flavonoids. The methanol and aqueous extracts presented considerable amounts of the flavanol (-)-epicatechin and the benzoic acid syringic acid [76]. Moreover, the aerial parts of $P$. macrostomum had the flavone luteolin (Figure 3) [67].

4.3. Essential Oils and Other Components. Dilek et al. [77] evaluated the essential oil composition of $P$. somniferum flowers after extraction by the hydrodistillation method. It mainly included $n$-nonadecane (9.0\%), heneicosane (10.8\%), $n$-pentacosane (7.9\%), palmitic acid (7.3\%), and 1nonadecanol (16.3\%) [77] (Figure 3). In another work, Krist et al. [78] identified the main volatile compounds in $P$. somniferum seed oil samples were 1-pentanol (3.3-4.9\%), 1-hexanal (10.9-30.9\%), 1-hexanol (5.3-33.7\%), 2pentylfuran (7.2-10.0\%), and caproic acid (2.9-11.5\%). It seems that the plant part could determine the composition of the volatile constituents, but little work has been done to investigate it.

The essential oil of the aerial parts of $P$. rhoeas that was gathered from the Elazig region in Turkey was obtained by hydrodistillation and analyzed using gas chromatography. Twenty-one constituents comprised the $98.6 \%$ of the total essential oil volatiles extracted from the plant. The major ones were phytol (52.8\%), tricosane (7.8\%), 2-pentadecanone (6\%), and heneicosane (5.3\%) (Figure 3); some of them are in common with $P$. somniferum [79]. Among them, the diterpene phytol is another interesting bioactive compound [80].

Moreover, the triglyceride composition of $P$. somniferum seed oil has been analyzed by matrix-assisted laser desorption/ionization-time-of-flight-MS and electrospray ionization ion trap-MS/MS. It enables the determination of the major triglyceride components, which were composed of linoleic, oleic, and palmitic acid, comprising approximately $70 \%$ of the oil [78]. The presence of high amount of unsaturated fatty acids makes the poppy seed oil suitable for its application in foods for maintaining the cardiovascular health.

4.4. Phytochemical Variation. The type of phytochemical and its content mainly depend on the part used and solvent applied for the extraction, as it was discussed in the previous sections. Also, intraspecific variation occurs [51, 59], for example, due to different locations [59], growth stage, and conditions [181]. This is extremely important for standardization or to choose those plants with strong enough potency to be applied to obtain functional ingredients.

For example, in a relevant study, empty poppy capsules (poppy straw) of 15 cultivars of $P$. somniferum were studied for the phytochemical profile. The seeds were raised in randomised block design with 3 replications during three consecutive years in 2007, 2008, and 2009. The extracts from the poppy straw were prepared using $5 \%$ acetic acid under sonication and then analyzed using liquid chromatography-MS. The overall results showed that the ratio of the alkaloids, morphine, codeine, narcotine, papaverine, and thebaine was highly variable in the selected 15 poppy cultivars, more than the difference found between the years [81].

\section{Biological Activities of the Papaver Genus}

Papaver forms part of the traditional system of medicines that plays an important role in providing health care to large section of the world population. Therefore, in this section, we discuss the updated snapshot of the bioactivities and therapeutic applications of Papaver genus, some of them related to its traditional use (Table 1).

5.1. Analgesic Activities. Few studies have already recognized that the treatment addressed to the immune system modulates the analgesic effect of the opiates isolated from poppy plant. It seems that during illness, the inhibition of morphine analgesia is due not only to the offsetting of analgesia by enhanced pain sensitivity but the action of endogenous antianalgesic mechanisms can be implied. The role of $N$-methyl-D-aspartate and central opioid receptors was established by Johnston 
Phenolic compounds<smiles>Oc1ccc(-c2[o+]c3cc(O)cc(O)c3cc2O)cc1</smiles><smiles>COc1cc(C(=O)O)cc(OC)c1O</smiles>

(syringic acid)<smiles>Oc1cc(O)c2c(c1)O[C@H](c1ccc(O)c(O)c1)[C@H](O)C2</smiles>

((-)-epicatechin)

((-)-epicatechin)<smiles>O=c1cc(-c2ccc(O)c(O)c2)oc2cc(O)cc(O)c12</smiles><smiles>[R2]c1cc(-c2oc3c([R])c(O)cc(C)c3c(=O)c2O)ccc1O</smiles>

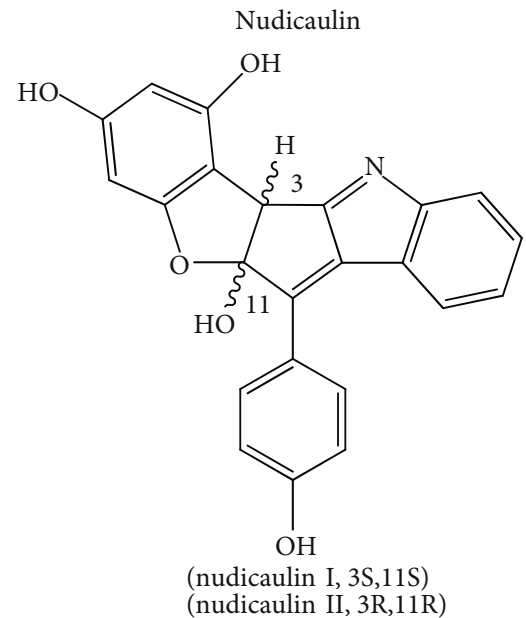

Volatile compounds

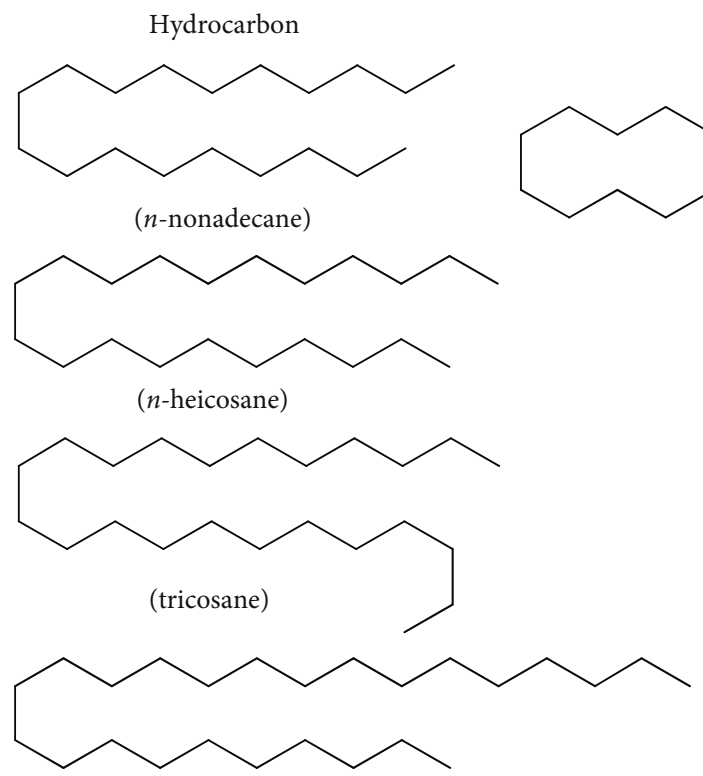

Fatty acid<smiles>CCCCCC(=O)O</smiles><smiles>CCCCCCCCCCCCCCCCO</smiles>

(palmitic acid)

(1-nonadecanol)

Diterpenic alcohol<smiles>C/C(=C\CO)CCC[C@H](C)CCC[C@H](C)CCCC(C)C</smiles><smiles>CCCCCCCCCCCCCC(C)=O</smiles>

(n-pentacosane)

FIgURE 3: Phenolic compounds structures and main volatile compounds identified in Papaver plants.

and Westbrook [82], as well as the glial activation in the spinal cord. Other Papaver species have revealed some analgesia properties. Ibrar and group [83] reported the analgesic activity of the Papaver pavoninum C.A. Mey. extract. The study was completed on a mouse model, and the results demonstrated that plant extract significantly reduced pain in mice at all the three doses $(50,100$, and $150 \mathrm{mg} / \mathrm{kg}$ body weight), as indicated by reduction in number of writhes as 36.91, 
57.01 , and $68.39 \%$, respectively. The reduction in pain was dose dependent; hence, the $150 \mathrm{mg} / \mathrm{kg}$ dose proved to be most effective than the standard analgesic drug. Similarly, the ethanolic extract from the aerial parts of Papaver libanoticum Boiss., an endemic plant to Lebanon, exhibited a potent dose-dependent analgesic activity, which involved activation of opioid receptors in the central nervous system. This activity could be attributed due to the presence of alkaloids, different to morphine or its derivatives, and phenolic compounds [178].

Alternatively, besides to have mild opioid activity [178], Shams et al. [84] tested the effect of the administration of a hydroalcoholic extract from $P$. rhoeas to mice to evaluate the analgesic tolerance induced by morphine $(1-10 \mathrm{mg} / \mathrm{kg})$ using the tail-flick method. The results indicated that the extract of $P$. rhoeas showed no effects on analgesia at 25$100 \mathrm{mg} / \mathrm{kg}$. However, treated animals with different doses of the extract $(25-100 \mathrm{mg} / \mathrm{kg})$ before the administration of morphine were effective to decrease the analgesic tolerance promoted by morphine.

5.2. Cytotoxicity Studies and Anticancer Activity. Several studies have shown that Papaver genus, including P. somniferum, P. rhoeas, Papaver lacerum Popov, and P. nudicaule, can provide anticancer compounds, but most studies were performed in vitro or in silico ([85, 86]; [179]; [87-89]), as shown in Table 3. Their efficacy depends again on the part and solvent used [88]. Moreover, among the studied compounds, alkaloids have shown anticancer properties [86, 87]. Nonetheless, the most active alkaloids were berberine and macranthine; importantly, they demonstrated low toxicity against the Vero cell line, a noncancerous model. P. somniferum-based nanoparticles ( $\mathrm{PbO}$ and $\mathrm{Fe}_{2} \mathrm{O}_{3}$ ) have shown cytotoxicity in HepG2 cell lines in order to treat hepatic carcinoma [87]. PbO-based nanoparticles demonstrated higher cytotoxicity ( $79 \%$ inhibition) owing to more penetration due to its smaller size as compared to $\mathrm{Fe}_{2} \mathrm{O}_{3}$ nanoparticles (61\% inhibition).

In another work, the chemical extracts from the petals of $P$. rhoeas have recently been tested for potential in the prevention of skin cancer. Sublethal UVB-mediated lesions at both DNA and RNA levels in human keratinocytes were observed, and thus, derived sunscreen based on the extracts of Papaver petals could be promising [90]. As commented before, petals can have phenolic compounds, other potential active compounds.

The lethality to brine shrimp can be applied as prescreen to existing cytotoxicity and antitumor assays [91]. In this context, other studies have tested Papaver extracts in brine shrimp eggs [91, 92]. It was established that the most active extract was obtained from $P$. pavoninum whole plant extracted with ethanol (lethal concentration $50 \%$ or $\mathrm{LC}_{50}=$ $2.54 \mu \mathrm{g} / \mathrm{mL}$ ) compared to $P$. rhoeas seed extracts obtained with dichloromethane $\left(\mathrm{LC}_{50}=24 \mu \mathrm{g} / \mathrm{mL}\right)$ and methanol $\left(\mathrm{LC}_{50}=26 \mu \mathrm{g} / \mathrm{mL}\right)[83,92]$. Since the latter $\mathrm{LC}_{50}$ values were lower than $30 \mu \mathrm{g} / \mathrm{mL}$, these extracts displayed significant cytotoxicity, according to Khalighi-Sigaroodi et al. [91], who tested extracts from other 23 plant species of the Leguminosae family.
Concerning in vivo studies, cytotoxicity has been mainly focused on concrete alkaloids and also the mechanisms of action studied in cancerous cell lines. Besides the aforementioned studies, the nonnarcotic alkaloids noscapine and papaverine have been found as potent anticancer agents against different human cancers such as breast, liver, bone, prostate, colorectal, and fibrosarcoma by inhibiting the cell proliferation, inducing apoptotic cell death, and causing cell cycle arrest [93].

Noscapine has been found to suppress the cell proliferation, migration, and invasion as well as also induce apoptosis. The supplementation of noscapine at the rate of $320 \mu \mathrm{M}$ concentration to human skin cancer cell line (A-431) induced $80 \%$ cell death and induced the structural change in human serum albumin protein $[94,95]$. Noscapine also presents strong anticancer potential against human epithelial ovarian and prostate cancers via inducing apoptosis in a receptor-dependent but radical oxygen species- (ROS-) independent manner [96]. Noscapine has anticancer activity against two LNCaP and PC-3 human prostate cancer cell lines, but it was combined with paclitaxel. This combination produced significantly lowering the mRNA expression of Bcell CLL/lymphoma (Bcl-2) and increasing the mRNA expression of $\mathrm{Bcl}-2$-associated $\mathrm{X}$ protein (Bax), and $\mathrm{Bax} /$ $\mathrm{Bcl}-2$ ratio, among other effects [97]. In this regard, the apoptosis of cancerous cells is regulated by the members of the Bcl-2 family (Bax, Bcl-2). Bcl-2 factors inhibit the apoptosis whereas Bax factors promote it; hence, the ratio of both the factors decides the fate of cancerous cells. Noscapine also improved its therapeutic anticancer potential in colon cancer SW480 cells through inducing apoptotic cell death by blocking the liver-intestine cadherin (CDH17) gene. It also shows a significant effect on the levels of proteins related to apoptosis (Cyt-c, Bax, Bcl-2, and Bcl-xL) [98]. In human SW480 colon cancer cells, noscapine markedly decreased the colony-forming ratio and cell viability, up-regulated the expression levels of cleaved-poly (ADP-ribose) polymerase and cleaved-caspase-3, inhibited cell proliferation, and promoted cell apoptosis [99]. Alternatively, another study proved that noscapine has been found effectively to inhibit proliferation and invasion of MG63 cell line by suppressing the phosphorylation of epidermal growth factor receptor (EGFR) gene and its downstream pathway [100].

There are also numerous studies on the anticancer effects of papaverine in cells. For example, papaverine exhibited anticancer activity on human glioblastoma (GBM) temozolomide (TMZ; as a first-line anticancer medicine)-sensitive U87MG and TMZ-resistant T98G cells via preventing tumor cell growth, suppressed cell migration, and significantly inhibited the cell proliferation. It was also reported that papaverine has a dose-dependent cytotoxic effect on human prostate cancer cells (PC-3) through inducing early and late apoptosis along with inducing sub-G1 cell cycle arrest, lowering the expression levels of $\mathrm{Bcl}-2$ proteins, increasing the Bax protein levels, reducing the NF- $\kappa$ B levels, and downregulating the PI3K and phospho-Akt expression [101, 102]. This observation is in line with Antonarakis et al. [103] who also reported other mechanisms such as an enhancement in the expression levels of Bax protein, the release of 
Table 3: Cytotoxicity of the Papaver genus.

\begin{tabular}{lc}
\hline Species/extract name & Design/model \\
\hline $\begin{array}{l}\text { P. somniferum L. } \\
\text { Lead and iron oxide nanoparticles }\end{array}$ & In vitro study \\
& \\
& \\
& \\
P. Lacerum Popov cell lines & In vitro study \\
& HeLa cell line \\
In silico study
\end{tabular}

$P$. nudicaule $\mathrm{L}$. (nudicaulin and derivatives) Methanol-water

P. rhoeas L. Ethanol extract

Papaver alkaloids (amurine, armepavine, berberine, isocorydine, isothebaine, macranthine, mecambrine, mecambridine, narkotine, orientalidine, oripavine, salutaridine, and thebaine)

P. somniferum $\mathrm{L}$.

Hexane, methanol, and ethyl acetate

\section{P. rhoeas $\mathrm{L}$}

Methanol extract

P. pavoninum Fisch \& Mey. Ethanol extract

Key effects

Countries References

(i) $\mathrm{PbO}$ NPs showed higher cytotoxicity

(20.9\%) as compared to $\mathrm{Fe}_{2} \mathrm{O}_{3}$ NPs (38.5\%)

(ii) The cytotoxicity of whole plant extract

Pakistan

(57.6\%) was lower than both NPs

(i) Two compounds, namely, tyrosol-1-O- $\beta$ xylopyranosyl-( $1 \rightarrow 6)-O-\beta$-glucopyranoside) (I) and 5-O-(6-O- $\alpha$-rhamnopyronosyl- $\beta$ glucopyronosyl) mevalonic acid (II), were isolated from this species

(ii) Both compounds exhibited modest Turkey cytotoxic effect, $\mathrm{IC}_{50}=66.4 \mu \mathrm{M}$ and $54 \mu \mathrm{M}$, respectively

(iii) In silico study showed that proteintyrosine kinase Syk and aldo-keto reductase

family-1 were the targets, respectively

(i) Synthetic nudicaulin derivatives 6-11

In vitro study

HeLa, HUVEC and $\mathrm{K}-562$ cell

lines

In vitro study

HCT116, MCF7,

$\mathrm{HaCaT}$, and

NCM460 cell lines

showed high antiproliferative activity against HUVEC and K-562 cells

(ii) Derivative compounds showed significant cytotoxic activity against HeLa cells

(i) The compounds stylopine, canadine, sinactine, berberine, and epiberberine and the raw extract showed a dose-dependent inhibitory effect. The highest activity was found for compound berberine against all cell lines (HCT116: $\mathrm{IC}_{50}=90 \mu \mathrm{M}$; MCF7: I

$\mathrm{C}_{50}=15 \mu \mathrm{M} ; \mathrm{HaCaT}: \mathrm{IC}_{50}=50 \mu \mathrm{M} ; \mathrm{NCM} 460$ :

$$
\left.\mathrm{IC}_{50} \geq 200 \mu \mathrm{M}\right)
$$

(i) Berberine and macranthine were the most active alkaloids in all 13 compounds

In vitro study (ii) Dose-dependent studies were applied and HeLa, and Vero cell lines

revealed $\mathrm{IC}_{50}$ values of $12.08 \mu \mathrm{g} / \mathrm{mL}$ (HeLa) and $71.14 \mu \mathrm{g} / \mathrm{mL}$ (Vero) for berberine, and $24.16 \mu \mathrm{g} / \mathrm{mL}$ (HeLa) and $\mathrm{IC}_{50}$ of $>300 \mu \mathrm{g} / \mathrm{mL}$ (Vero) for macranthine

(i) The inhibitory effects of the leaf, root, stem, and capsule extracts were shown on cancer cell lines

In vitro study HT29, HeLa, C6 cells, and Vero cell lines

In vitro study TK6 cell lines

In vitro study Brine shrimp eggs (ii) The extracts were able to destroy cellular membrane in tumor cell lines at high concentrations

(iii) Stem ethyl acetate extract exhibited strong anticancer activity on all cell lines, with $\mathrm{IC}_{50}$ values ranged from 119 to $391 \mu \mathrm{g} / \mathrm{mL}$ ), depending on the plant part and solvent

(i) The highest inhibition of cell growth was observed at the concentrations of $5 \mathrm{mg} / \mathrm{mL}$ and $25 \mathrm{mg} / \mathrm{mL}$ after the treatment with plant extract

(i) The plant extract was found to produce outstanding dose-dependent cytotoxicity in terms of $\mathrm{LC}_{50}=2.54 \mu \mathrm{g} / \mathrm{mL}$

(ii) The dose concentration of 100 and $1000 \mu \mathrm{g} / \mathrm{mL}$ produced high cytotoxicity as $83.3 \%$ and $96.7 \%$ lethality, respectively
Turkey

Germany

Lebanon

Turkey

Slovakia

Pakistan 
TABLE 3: Continued.

\begin{tabular}{|c|c|c|c|c|}
\hline Species/extract name & Design/model & Key effects & Countries & References \\
\hline $\begin{array}{l}P . \text { rhoeas L. } \\
n \text {-Hexane, dichloromethane, } \\
\text { and methanol }\end{array}$ & $\begin{array}{l}\text { In vitro study } \\
\text { Brine shrimp } \\
\text { eggs }\end{array}$ & $\begin{array}{l}\text { (i) Dichloromethane and methanol extracts } \\
\text { showed significant toxicity activity in brine } \\
\text { shrimp lethality assay in terms of } \mathrm{LC}_{50} 24 \\
\text { and } 26 \mu \mathrm{g} / \mathrm{mL} \text {, respectively }\end{array}$ & $\begin{array}{l}\text { United } \\
\text { Kingdom }\end{array}$ & [92] \\
\hline
\end{tabular}

$\mathrm{IC}_{50}: 50 \%$ inhibitory concentration; $\mathrm{LC}_{50}$ : lethal concentration $50 \%$; NPs: nanoparticles.

cytochrome $\mathrm{C}$ into the cytoplasm, reduction in the expression levels of X-linked inhibitor of apoptosis protein, and induction of apoptosis. Papaverine was also found effective against hepatic carcinoma by inhibiting the telomerase through downregulation of telomerase reverse transcriptase in humans in HepG-2 cells [104]. Likewise, noscapine and papaverine have an anticancer effect on human MCF-7 and MDA-MB-231 cell lines via enhancing apoptosis, causing cell cycle at $\mathrm{G} 2 / \mathrm{M}$ phase, and arresting cell cycle at $\mathrm{G}_{0} /$ $\mathrm{G}_{1}$ phase [105].

Moreover, papaverine in combination with lowfrequency ultrasound improved the blood-brain barrier, which is involved in the maintenance of brain homeostasis and compromised in brain tumors [106, 107]. This combination was able to reduce the expression levels of zonula occluden-1, occludin, and claudin-5, enhancing the permeability of blood-tumor barrier. This can be a strategy for selective crossing this barrier by chemotherapeutic drugs [107]. Another in vivo study showed that papaverine also markedly delayed the tumor growth in a U87MG xenograft mouse model [108, 109].

Besides the latter compounds, sanguinarine is another promising anticancer compound effective against a variety of multidrug-resistant cancers and combined with chemotherapeutic agents to synergistically enhance their sensitivity [110]. Also, berberine has shown anticancer potential in cells ([87]; [179], among others, as Table 3 shows.

5.3. Antimicrobial Activity and Antiviral Activities. The antimicrobial activity of several extracts from Papaver plants is shown in Table 4. Among these studies, P. somniferum seed extracts, containing alkaloids and phenolic compounds, among other components, have shown the highest antimicrobial activity for the methanol extract against Staphylococcus aureus and Aspergillus species [111], whereas the aqueous and ethanolic extracts against root rot fungi at 5\% [112]. In another work, AMA of P. somniferum in nanosystem was evaluated when it was used for the green synthesis of nanoparticles based on lead oxide $(\mathrm{PbO})$ and iron oxide $\left(\mathrm{Fe}_{2} \mathrm{O}_{3}\right)$. Both the nanoparticles resulted in effective antimicrobial activity against all the pathogenic microbial strains (Bacillus subtilis, Staphylococcus epidermidis, Klebsiella pneumoniae, Pseudomonas aeruginosa, Fusarium solani, Aspergillus flavus, Aspergillus fumigates, and Aspergillus niger) in a dose-dependent manner ( 4 to $10 \mathrm{mg} / \mathrm{mL}$ concentration) [102]. However, Papaver-based fabrication of $\mathrm{PbO}$ nanoparticles resulted in higher antibacterial property due to its small size than $\mathrm{Fe}_{2} \mathrm{O}_{3}$-based nanoparticles.

In a comparison study performed by Ünsal and coworkers [113], the antimicrobial extracts obtained with various solvents from the aerial parts of $P$. argemone, $P$. dubium, P. rhoeas, and Papaver clavatum Boiss. \& Hausskn. ex Boiss. were recently investigated. Among the solvent tested, $P$. dubium extracted by petroleum ether and diethyl ether showed a higher effectiveness against $S$. aureus, with a minimum inhibitory concentration (MIC) of 9.76 and $19.52 \mu \mathrm{g} / \mathrm{mL}$, respectively, compared to chloroform, ethanol, and acetone. Even, lower values have been reported for the tertiary alkaloids obtained from the aerial parts of $P$. rhoeas when it was tested against six bacterial species ( $S$. aureus, $S$. epidermidis, Escherichia coli, K. pneumoniae, P. aeruginosa, and Proteus mirabilis), and three Candida strains (C. albicans, C. parapsilosis, and C. tropicalis) were studied using a microbroth dilution method. In this study, the plant samples were collected from 11 different sites, obtaining the best antimicrobial activity against $S$. aureus and $C$. albicans with an MIC value of 1.22 and $2.42 \mu \mathrm{g} / \mathrm{mL}$ in the site with the higher content of roemerine alkaloid [64]. Additionally, Table 4 displays the antimicrobial activity of other Papaver species. Among them, the results of Papaver pseudocanescens M. Pop extracts as an antiviral agent seem promising [114].

In a similar way, the antiviral activities of active compounds of $P$. rhoeas pollen against influenza H1N1, H3N2, and $\mathrm{H} 5 \mathrm{~N} 1$ viruses have been evidenced. Total, six flavonoids, including kaempferol derivatives and luteolin, and one alkaloid, chelianthifoline, were isolated and revealed neuraminidase inhibitory activities, reducing the ability of the virus to spread. The concentration required for $50 \%$ inhibition $\left(\mathrm{IC}_{50}\right)$ ranged from 10.7 to $100.5 \mu \mathrm{M}$ for $\mathrm{H} 1 \mathrm{~N} 1$, 25.6 to $143.2 \mu \mathrm{M}$ for $\mathrm{H} 3 \mathrm{~N} 2$, and 12.6 to $151.1 \mu \mathrm{M}$ for H5N1. Among all tested compounds, luteolin was found to be the most active [115]. The antimicrobial activity of nudicaulin derivatives (synthesized in vitro and in vivo in $P$. nudicaule) has also been evaluated, but only one derivative (17-methyl-5,7,11,3', $4^{\prime}$-penta-O-methylnudicaulin) was slightly active [86].

5.4. Antioxidant Activity. The in vitro antioxidant activity of $P$. somniferum has been reported by using different methods, including the 2,2-diphenyl-1-picrylhydrazyl (DPPH), 2' -azinobis-(3-ethylbenzothiazoline-6-sulfonate) (ABTS), and chelating assays [119] (Table 5). Zhang and coworkers from China described the antioxidant activity of the powdered poppy capsule extractive by using DPPH assay and its relationship with quantitative fingerprinting. Morphine and codeine were among the components that have a positive influence in this bioactivity [120]. This agreed with the results obtained by other authors [121]. Moreover, a recent study evaluating different parts of the plant suggests that 
Table 4: Antimicrobial activity of Papaver plants.

\begin{tabular}{|c|c|c|c|c|c|}
\hline Species/extract name & Microbial strains & Key results & Assay & Country & References \\
\hline \multirow{8}{*}{$\begin{array}{l}\text { P. somniferum L. } \\
\text { Hexane, methanol, ethanol, } \\
\text { and ethyl acetate extract }\end{array}$} & Bacillus cereus MTCC 430 & $0.14 \mathrm{~mm}$ ZOI & \multirow{8}{*}{ Disc-diffusion } & \multirow{8}{*}{ India } & \multirow{8}{*}[111]{} \\
\hline & Staphylococcus aureus MTCC 3160 & $2.00 \mathrm{~mm} \mathrm{ZOI}$ & & & \\
\hline & Escherichia coli MTCC 40 & $0.10 \mathrm{~mm}$ ZOI & & & \\
\hline & Salmonella typhi MTCC 3224 & $0.13 \mathrm{~mm}$ ZOI & & & \\
\hline & Aspergillus niger MTCC 281 & $3.00 \mathrm{~mm}$ ZOI & & & \\
\hline & Aspergillus oryzae MTCC 624 & $3.00 \mathrm{~mm} \mathrm{ZOI}$ & & & \\
\hline & Aspergillus flavus MTCC 227 & $1.50 \mathrm{~mm} \mathrm{ZOI}$ & & & \\
\hline & Penicillium chrysogenum MTCC 6795 & $2.00 \mathrm{~mm} \mathrm{ZOI}$ & & & \\
\hline \multirow[b]{2}{*}{$\begin{array}{l}\text { P. pseudocanescens M. Pop } \\
\text { Ethanol extract }\end{array}$} & Poliovirus type 1 (LSc-2ab) & $21.4-49.7 \mu \mathrm{M} \mathrm{IC}_{50}$ & \multirow[b]{2}{*}{-} & \multirow[b]{2}{*}{ Bulgaria } & \multirow[b]{2}{*}[114]{} \\
\hline & $\begin{array}{l}\text { Human rhinovirus type } 14 \\
\text { (HRV-14) }\end{array}$ & $65-199 \mu \mathrm{M} \mathrm{IC}_{50}$ & & & \\
\hline \multirow{7}{*}{$\begin{array}{l}\text { P. rhoeas L. } \\
\text { Methanol, ethanol, water, } \\
\text { and alcoholic-water extract }\end{array}$} & Bacillus subtilis ATCC 6633 & - & \multirow{7}{*}{ Disc-diffusion } & \multirow{7}{*}{ Serbia } & \multirow{7}{*}[70]{} \\
\hline & Staphylococcus aureus ATCC 6538 & $12-18 \mathrm{~mm} \mathrm{ZOI}$ & & & \\
\hline & Escherichia coli ATCC 8739 & $17-24 \mathrm{~mm} \mathrm{ZOI}$ & & & \\
\hline & Pseudomonas aeruginosa ATCC 9027 & $11-20 \mathrm{~mm} \mathrm{ZOI}$ & & & \\
\hline & Salmonella abony NCTC 6017 & - & & & \\
\hline & Aspergillus niger ATCC 16404 & $13-26 \mathrm{~mm} \mathrm{ZOI}$ & & & \\
\hline & Candida albicans ATCC 10231 & - & & & \\
\hline \multirow{7}{*}{$\begin{array}{l}\text { P. somniferum L. bee pollen } \\
\text { Ethanol extract }\end{array}$} & Penicillium citrininum & $4-5 \mathrm{~mm} \mathrm{ZOI}$ & \multirow{7}{*}{ Disc-diffusion } & \multirow{7}{*}{ Slovak } & \multirow{7}{*}[116]{} \\
\hline & Penicillium crustosum & 4-9 mm ZOI & & & \\
\hline & Penicillium expansum & $1-4 \mathrm{~mm}$ ZOI & & & \\
\hline & Penicillium brevicompactum & $1-3 \mathrm{~mm} \mathrm{ZOI}$ & & & \\
\hline & Penicillium chrysogenium & - & & & \\
\hline & Enterobacteriaceae & 6-7 mm ZOI & & & \\
\hline & Staphylococcus sp. & 5-6 mm ZOI & & & \\
\hline \multirow{7}{*}{$\begin{array}{l}\text { P. argemone L. subsp. davisii } \\
\text { Petroleum ether, diethyl ether, } \\
\text { chloroform, acetone, and } \\
\text { ethanol extract }\end{array}$} & Staphylococcus aureus ATCC 65538 & 39-625 $(\mu \mathrm{g} / \mathrm{mL}) \mathrm{MIC}$ & \multirow{7}{*}{$\begin{array}{l}\text { Microbroth } \\
\text { dilutions }\end{array}$} & \multirow{7}{*}{ Turkey } & \multirow{7}{*}[113]{} \\
\hline & $\begin{array}{c}\text { Staphylococcus epidermidis } \\
\text { ATCC } 12228\end{array}$ & $312-1250(\mu \mathrm{g} / \mathrm{mL}) \mathrm{MIC}$ & & & \\
\hline & Escherichia coli ATCC 25922 & $1250(\mu \mathrm{g} / \mathrm{mL}) \mathrm{MIC}$ & & & \\
\hline & Klebsiella pneumonia ATCC 4352 & $1250(\mu \mathrm{g} / \mathrm{mL}) \mathrm{MIC}$ & & & \\
\hline & Pseudomonas aeruginosa ATCC 27853 & $625-1250(\mu \mathrm{g} / \mathrm{mL}) \mathrm{MIC}$ & & & \\
\hline & Proteus mirabilis ATCC 14153 & $1250(\mu \mathrm{g} / \mathrm{mL}) \mathrm{MIC}$ & & & \\
\hline & Candida albicans ATCC 10231 & $312-625(\mu \mathrm{g} / \mathrm{mL}) \mathrm{MIC}$ & & & \\
\hline \multirow{7}{*}{$\begin{array}{l}\text { P. clavatum Boiss. \& } \\
\text { Hausskn. ex Boiss } \\
\text { Petroleum ether, diethyl ether, } \\
\text { chloroform, acetone and } \\
\text { ethanol extract }\end{array}$} & Staphylococcus aureus ATCC 65538 & 78-156 ( $\mu \mathrm{g} / \mathrm{mL}) \mathrm{MIC}$ & \multirow{7}{*}{$\begin{array}{l}\text { Microbroth } \\
\text { dilutions }\end{array}$} & \multirow{7}{*}{ Turkey } & \multirow{7}{*}[113]{} \\
\hline & Staphylococcus epidermidis ATCC 12228 & $312-625(\mu \mathrm{g} / \mathrm{mL}) \mathrm{MIC}$ & & & \\
\hline & Escherichia coli ATCC 25922 & $312-625(\mu \mathrm{g} / \mathrm{mL}) \mathrm{MIC}$ & & & \\
\hline & Klebsiella pneumonia ATCC 4352 & - & & & \\
\hline & Pseudomonas aeruginosa ATCC 27853 & - & & & \\
\hline & Proteus mirabilis ATCC 14153 & $625(\mu \mathrm{g} / \mathrm{mL}) \mathrm{MIC}$ & & & \\
\hline & Candida albicans ATCC 10231 & $625(\mu \mathrm{g} / \mathrm{mL}) \mathrm{MIC}$ & & & \\
\hline
\end{tabular}


TABLE 4: Continued.

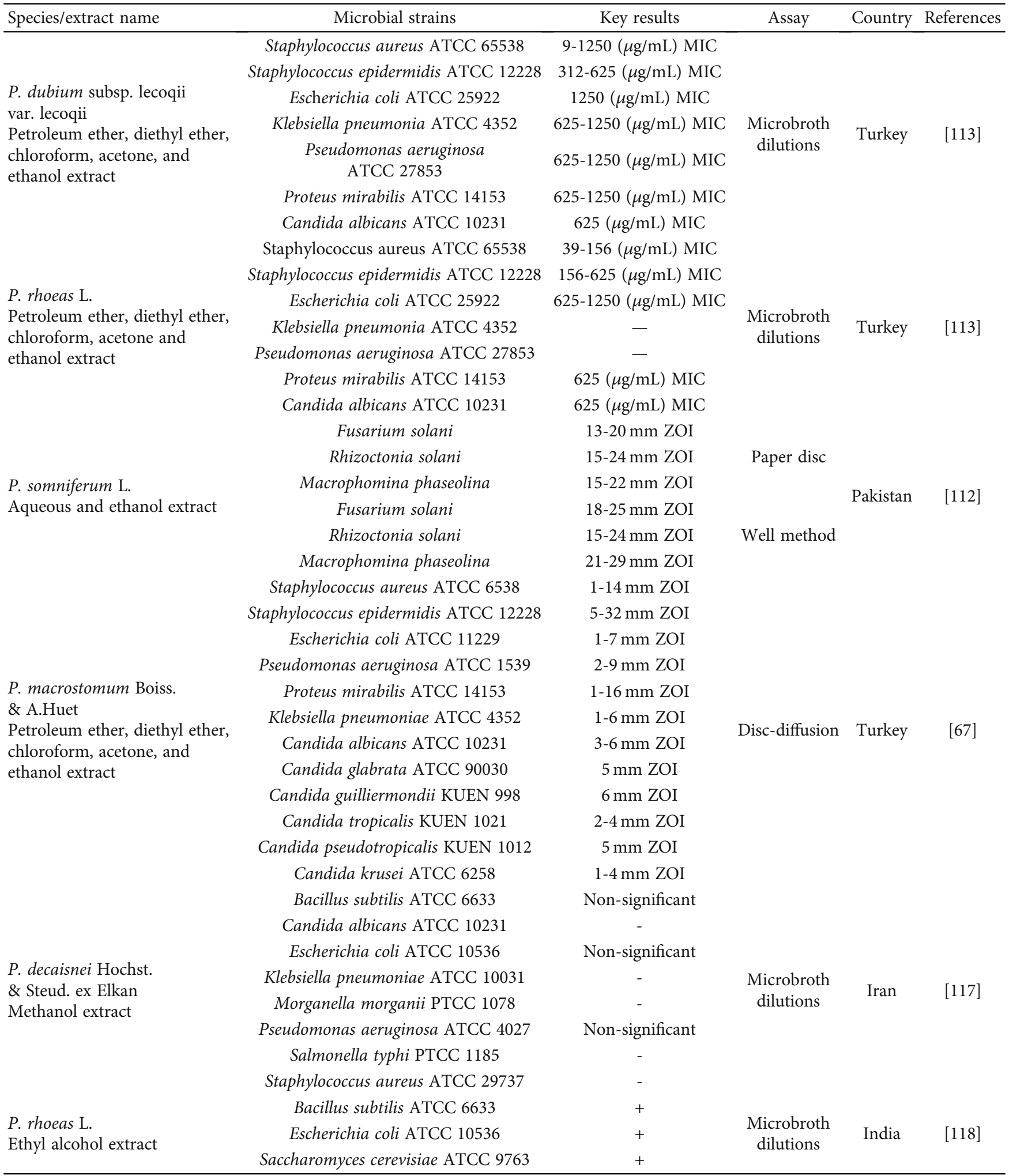

$\mathrm{IC}_{50}$ : inhibitory concentration at 50\%; MIC: minimum inhibitory concentration; ZOI: zone of inhibition; -: not active; +: active.

the flower extract (rich in anthocyanins) and leaves showed the highest antioxidant activity depending on the antioxidant assay. Although it correlated with the phenolic content, the alkaloid extract showed the highest antioxidant values, with inhibitory concentration $\left(\mathrm{IC}_{50}\right)$ of 7.4 and $8.1 \mu \mathrm{g} / \mathrm{mL}$ in the DPPH and ABTS radical scavenging activity assays [122]. In another context, the antioxidant activity of $\mathrm{PbO}$ and $\mathrm{Fe}_{2} \mathrm{O}_{3}$ nanoparticles synthesized using $P$. somniferum 
was evaluated. Using free radical scavenging assay (FRS), total reducing power assay (TRP), and total antioxidant capacity assay (TAC), it was observed that both the nanoparticles of $P$. somniferum exhibited concentration-dependent activity. $\mathrm{PbO}$ nanoparticles revealed the significant antioxidant activity in terms of FRS (54\%), TRP (16.8 mg ascorbic acid equivalents/mg), and TAC (106.1 mg ascorbic acid equivalents/mg) while $\mathrm{Fe}_{2} \mathrm{O}_{3}$ nanoparticles showed 52\% FRS activity, $16.8 \mathrm{mg}$ ascorbic acid equivalents/mg TRP, and 131.1 ascorbic acid equivalents/mg TAC, respectively [102].

The antioxidant activity in vivo of $P$. somniferum has been also evaluated through the seed oil administered to rats, observing limited oxidative damage [123]. Concerning other species, the antioxidant activity of $P$. rhoeas has also been reported by three methods: DPPH, ABTS, and ferric reducing antioxidant power (FRAP) assays. The results clearly indicated that leaf extract demonstrated significant antioxidant activity with a half-maximal effective concentration $\left(\mathrm{EC}_{50}\right) 28.72 \mathrm{mg} / 100 \mathrm{~g}$ dry weight in DPPH, $185.29 \mathrm{mM}$ $\mathrm{Fe}^{2+} / 100 \mathrm{~g}$ DW in FRAP, and $12.07 \mathrm{mM}$ Trolox equivalents (TE)/100 g dry weight in ABTS [124]. The water extract of this plant has also been evaluated for antioxidant potential using DPPH and superoxide anions assays. The $\mathrm{IC}_{50}$ value of $P$. rhoeas was $4.81 \mathrm{mg} / \mathrm{mL}$ for DPPH assay, and it was the highest antioxidant activity in the anti-ROS assay [125]. Moreover, the hydrophilic and lipophilic antioxidant activity of $P$. rhoeas was studied by using the TEAC assay. The leaves of wild $P$. rhoeas displayed the highest total antioxidant activity (1326 $\mu \mathrm{mol} \mathrm{TE} / 100 \mathrm{~g}$ fresh weight) among other assessed plant species, which correlated with their total phenolic and flavonoid content [126].

The antioxidant action of Papaver plants depends on the genotype as shown by Krošlák and coworkers. Their results suggested that there were differences in the antioxidant activity of P. somniferum seeds by using DPPH, ABTS, FRAP, and reducing power (RP) assays. The genotype major displayed the best antioxidant activity in all the assays, namely, DPPH (126.29), ABTS (31.05), FRAP (31.61), and RP (146.56) mg of TE. Alternatively, the genotype MS-423 showed the high inhibition against trypsin, thrombin, and collagenase enzymes [127]. Other important factor is the solvent used for extraction. The results by Selen Isbilir \& Sagiroglu [20] indicated that water extract (WE) of $P$. rhoeas was the most effective compared to ethanol (EE), and acetone extracts (AE); total antioxidant activity of all the extracts was recorded to be $96.01 \%$ (WE), $94.98 \%$ (EE), and $89.07 \%$ (AE), respectively. The TRP of extracts was as follows: WE $>\mathrm{EE}>\mathrm{AE}$ [20]. Other studies on antioxidant potential of Papaver genus are presented in Table 5, showing the selected solvent for extraction. Although it is difficult to compare all the solvents due to the use of different assays and units, it seems that the methanolic extract was higher in antioxidant activity compared to other solvents for the aerial parts of $P$. bracteatum.

From the aforementioned studies and Tables 4 and 5, it can be summarized that the bioactivity of the alkaloids derived from the Papaver genus depends on the extraction conditions, as the phytochemical composition. Extraction condition may include the type of the solvent, extraction time, temperature, and other input factors. In addition, Papaver alkaloids or phytochemical extracts demonstrated more effective bioactivities in the nanoforms. Smaller nanoparticles penetrate more easily into the bacterial membrane and dissociate into respective ions causing oxidative stress, membrane leakage, and killing bacterial cells with more perfection. The use of well-established alkaloids for the treatment of various ailments in the human body may be utilized as nanoformulation to enhance the efficacy of the drug. There is further need to develop the field of nanotechnology with respect to Papaver-based drug formulations. In addition, testing other isolated compounds is required to assess the antimicrobial activity and antioxidant potential and their contribution in order to select most active plant extracts.

5.5. Antidiabetic Activity. It is well known that $\alpha$-amylase and $\alpha$-glucosidase are key enzymes for the catabolism of complex carbohydrates into glucose and thus target to explore antidiabetic drugs. In this sense, the $\alpha$-glucosidase inhibitory activity of $P$. somniferum seeds (aqueous and ethanol extracts) was also demonstrated. It was found that both the extracts showed less than 5\% inhibitory activity [132]. Also, the $\alpha$-amylase enzyme inhibition activity using P. somniferum pod-based $\mathrm{PbO}$ and $\mathrm{Fe}_{2} \mathrm{O}_{3}$ nanoparticles showed insignificant inhibition as $3 \%$ and $25 \%$, respectively [102].

Apart from this, large number of researchers documented the antidiabetic potential of this genus in literature through traditional medicine knowledge [133-136]. Most of these studies referred to $P$. rhoeas and particularly to the seeds. For example, boiled seeds capsule of $P$. rhoeas were used by the communities with $22.85 \%$ frequency based on the information collected by 35 healers in Iran [37]. Alternatively, the antidiabetic effects of opium were low in experimental diabetic animals at an oral dose of $10 \mathrm{mg} / \mathrm{kg}$ body weight for 90 days, as reported by Ahmed and group. Although opium increased serum insulin and decreased serum glucose, the effect was not significant; this was due to metabolic disorders in diabetic animals. In addition, it is suggested that opium consumption in diabetic patient is not useful [137]. Similarly, Sadeghian et al. [138] reported the effects of available opium substance on glucose and lipid metabolism in streptozotocin-induced-diabetic rats by testing opium contained in the juice of the seed capsule of the $P$. somnniferum. The test rats were treated with normal opium $(20 \mathrm{mg})$, starting on the fifth day after induction of diabetes for 30 days. The results demonstrated that glycaemia levels in the rats treated with opium $(544.8 \mathrm{mg} / \mathrm{dl})$ were similar to the levels determined in the control rats $(524.6 \mathrm{mg} / \mathrm{dL})$. In addition, the level of other parameters was similar: serum, total cholesterol, high-density lipoprotein, and triglyceride. Indeed, more studies are needed to clarify the role of Papaver, specifically, P. rhoeas, in the antidiabetic action and the active chemical components.

5.6. Properties in Fertility. The role of $P$. rhoeas extract (dried petals macerated with $50 \%$ ethanol) on fertility has also been investigated in mouse oocytes [139]. The cumulus-oocyte complexes were cultured in a maturation 
TABle 5: Antioxidant activity of Papaver plants.

\begin{tabular}{|c|c|c|c|c|}
\hline Species and type of extract & Assay & Key results & Countries & References \\
\hline $\begin{array}{l}\text { P. rhoeas L. } \\
\text { Methanolic extract }\end{array}$ & DPPH & $\mathrm{IC}_{50}=1.4 \mathrm{mg} / \mathrm{mL}$ & Slovakia & {$[89]$} \\
\hline $\begin{array}{l}\text { P. somniferum L. } \\
\text { Ethanolic extract }\end{array}$ & Total reducing power & $3592.56 \mathrm{mg} / \mathrm{mL}$ & Serbia & {$[116]$} \\
\hline $\begin{array}{l}\text { P. rhoeas L. } \\
\text { Ethanolic extract }\end{array}$ & DPPH & $81.47-89.71 \%$ & Serbia & {$[70]$} \\
\hline $\begin{array}{l}\text { P. rhoeas L. } \\
\text { Methanolic extract }\end{array}$ & $\begin{array}{c}\text { CUPRAC } \\
\text { ABTS/persulfate } \\
\text { FRAP }\end{array}$ & $\begin{array}{l}0.13 \mathrm{mmol} \mathrm{TR} / \mathrm{g} \\
0.15 \mathrm{mmol} \mathrm{TR} / \mathrm{g} \\
0.07 \mathrm{mmol} \mathrm{TR} / \mathrm{g}\end{array}$ & Turkey & {$[128]$} \\
\hline $\begin{array}{l}\text { P. somniferum L. } \\
\text { Methanolic extract }\end{array}$ & Linoleic acid peroxidation & $49.75 \mathrm{IC}_{50}(\mu \mathrm{g} / \mathrm{mL})$ & Iran & [129] \\
\hline $\begin{array}{l}\text { P. bracteatum Lindl } \\
\text { Methanolic extract }\end{array}$ & Linoleic acid peroxidation & $\mathrm{IC}_{50}=3.51 \mu \mathrm{g} / \mathrm{mL}$ & Iran & {$[130]$} \\
\hline $\begin{array}{l}\text { P. rhoeas L. } \\
\text { Aqueous methanol extract }\end{array}$ & $\begin{array}{c}\mathrm{DPPH} \\
\mathrm{H}_{2} \mathrm{O}_{2} \\
\mathrm{Fe}^{2+}\end{array}$ & $\begin{array}{c}\mathrm{EC}_{50}=63.01(\mu \mathrm{g} / \mathrm{mL}) \\
10.57-52.70 \% \\
86.85 \%\end{array}$ & Turkey & {$[131]$} \\
\hline
\end{tabular}

ABTS: 2,2' -azino-bis(3-ethylbenzothiazoline-6-sulfonic acid; CUPRAC: cupric reducing antioxidant capacity; DPPH: 2,2-diphenyl-1-picrylhydrazyl; EC : $_{\text {- }}$ half-maximal effective concentration; $\mathrm{EC}_{50}$ : half-maximal effective concentration; FRAP: ferric-reducing antioxidant power; TR: Trolox.

medium supplemented with different concentrations (low: 10$25 \mu \mathrm{g} / \mathrm{mL}$; high: $50-200 \mu \mathrm{g} / \mathrm{mL}$ ) of $P$. rhoeas extract. Low concentrations of extract showed moderate effects; however, higher concentration $(100 \mu \mathrm{g} / \mathrm{mL})$ significantly improved the rate of oocyte maturation and embryo development in mouse oocyte maturation medium [139]. In another study, similar findings were obtained while working on sheep oocytes [140]. The results demonstrated that plant extract displayed dose-dependent activity in a maturation medium. The concentration of $50 \mu \mathrm{g} / \mathrm{mL}$ was effective and improved the sheep oocyte maturation rate when the extract was supplemented in a maturation medium [140]. Flavonoids, including anthocyanins, have been associated with these effects, which can protect intracellular glutathione levels in oocytes [141].

5.7. Neurological/Mental Effects. Supplementation of $P$. rhoeas hydroalcoholic extract reduced depression and increased the neurotransmitters involved in depression, including dopamine, serotonin, and norepinephrine [142]. Depression is also linked with stress and increases glucocorticoid secretion into the blood. Nonetheless, the administration of a hydroalcoholic extract of $P$. rhoeas $(15-60 \mathrm{mg} / \mathrm{kg}$ in male mice) enhanced the secretion of glucocorticoids, but it could reduce the side effects of stress [143]. In other work, $P$. rhoeas distillate decreased anorexia and improved learning ability, but it again increased the corticosterone levels [144]. These positive neurological/mental effects agreed with recent results that suggest that $P$. rhoeas hydroalcoholic extract has a reducing effect on depression in mice after short-term administration. In this sense, the antidepressant effect of $P$. rhoeas may not be due to the inhibition of the hypothalamic-pituitary-adrenal stress system, while it could be caused, at least in part, by the inhibition of glutamate or through antiopioid and anticholinergic effects [145].
Furthermore, sedative effects of $P$. rhoeas aqueous and alcoholic extracts have also been observed, being more marked when $10 \%$ ethanol was used as solvent for extraction [71].

5.8. Other Bioactivities. The antiulcerogenic activity of $P$. rhoeas root extract was assessed by using the ethanolinduced ulcerogenesis model in rats. The plant extract $(670 \mathrm{mg} / \mathrm{kg})$ exhibited statistically significant (95.6\%) gastroprotective effects. In addition, histopathological studies confirmed the positive results of the extract in vivo [146]. The anti-inflammatory activity of extracts from $P$. nudicaule aerial parts and its mode of action in RAW264.7 macrophage cells have been also tested. Interestingly, in this work, the aerial parts were selected according to different colors (white, orange, yellow, scarlet, and pink) and under two different growth stages (after 60 and 90 days). All of the extracts of $P$. nudicaule displayed significant effects in reducing lipopolysaccharide- (LPS-) induced nitric oxide; the white flower extract-90 showed the best results. This extract also decreased the LPS-induced nitric oxide synthase 2 and cyclooxygenase 2 . It inhibited the LPS-induced activation of nuclear factor $-\kappa \mathrm{B}$ and signal transducer and the activator of transcription 3 signalling pathway [147]. As commented before, the phenolic composition depends on the color and the white ones have petals rich in kaempferol glycosides, but with a lack of pelargonidin glycosides and nudicaulins [73]. Moreover, P. rhoeas extracts prevented pain and inflammation due to their potential activity on opioid, glutamate, and nitric oxide systems, as well as elevated the plasma corticosterone concentration [148]. Furthermore, P. somniferum seeds have inhibitory activities against trypsin, thrombin, and collagenase, suggesting more vast pharmacological possibilities [127]. 


\section{Safety and Adverse Effects}

An undesired harmful effect resulting from a medication or other intervention such as surgery is known as an adverse effect. It may be termed a "side effect," when considered to be secondary to the therapeutic effect [149]. In contrast, dangerous, unintended reactions of medicines that occur at doses normally used for treatment are called adverse drug reactions (ADRs), even can lead to death in many countries [149]. In the case of morphine alkaloids, the pharmacologic properties of these compounds differ widely and their medicinal applications have some safety and adverse effects [150].

Various wanted and unwanted effects of opium consumption are discussed in the encyclopedia Canon of Medicine by Avicenna (980-1037 AD). Avicenna has mentioned on the mechanism of opioid-related respiratory depression, due to respiratory muscle spasm for respiratory failure. Similarly, it is mentioned in Canon of Medicine that opium can cause abnormal and difficult breathing, which can lead to death. A respiratory suppression side effect was observed with patients suffering from fever associated with tuberculosis due to the use of the topical opioid application on the chest. Constipation and painful bowel obstruction were other adverse effects of opium-based [177]. Avicenna has also mentioned poisoning, sluggishness, sedation, and abdominal contractions. Opium has highly addictive qualities and is reported to cause memory and reasoning dysfunction [177].

Remarkably, modern studies have confirmed the adverse effect of morphine alkaloids described by Avicenna [151-153]. Some of them are related to the binding to $\mu$ and $\kappa$-opioid receptors, the accumulation of neuroexcitatory opioid metabolites, etc. One of the side effects of opioidbased pain relievers, including morphine and its derivatives, is severe constipation [154]. Kohberg et al. [155] and Rocker et al. [156] also reported constipation as the most frequent adverse effect. Moreover, other effects of morphine are on the CNS mediated by its high affinity to the $\mu$-opioid receptor, such as nausea, vomiting, sedation, euphoria, miosis, respiratory depression, drowsiness, and obstipation [157]. Additional adverse effects are endocrinopathies and sleep disorders. Furthermore, long-term use of opioid can lead opioid tolerance (increased dose needed for analgesia) and hyperalgesia (paradoxical increase in pain with opioid administration) that involves $\mu$-opioid receptor signalling pathways [158-160]. Wound healing can also be delayed by chronic morphine intake by inhibiting immune cell recruitment followed by wounding [161].

As codeine is a precursor of morphine, they share some pharmacological features with also direct activity at the opioid receptors, but the former has much lower potency. The most frequent side effects of codeine are constipation and nausea, and addition potential. Nevertheless, in some paediatric patients, the genotype predisposing to ultrarapid metabolism of codeine into morphine by the isoenzyme CYP2D6 can occur [157]. Codeine and morphine can be distributed into breast milk with complications for breastfed infants of mothers receiving codeine [162], even a case of severe neonatal toxicity in a breastfed infant has been reported [163]. In the case of noscapine, it is used as a centrally acting antitussive compound and no toxicological properties have been characterized, but it can present headache and dizziness [157].

Poppy seeds from $P$. somniferum are commercially available in some countries and widely used as ingredients for various kinds of food, especially in Eastern Europe [164]. Poppy seeds for food uses are generally obtained from cultivars bred to accumulate lower amounts of opium alkaloids [56] and normally contain low levels $(2-251 \mu \mathrm{g} / \mathrm{g}$ of morphine and 0.4-57 $\mu \mathrm{g} / \mathrm{g}$ of codeine) [165]. The opioid concentrations come primarily from the alkaloid residue retained on the seeds [166]. Therefore, although the consumption of poppy seeds in foods is really in small amounts, EFSA set a general safe level of $10 \mu \mathrm{g}$ per kilogram of body weight based on the morphine content of poppy seeds [157]. In this sense, only a rare case of death has been published consuming between 64 and 587 times the volume of poppy seeds (around $900 \mathrm{~g}$ ). This extremely high ingest led to death due to complications of a bowel obstruction, but it did not cause lethal opiate toxicity [165].

Alternatively, extracts or infusions concentrated in opium alkaloids from poppy seeds can have adverse effects $[56,165]$, but there are few reports on this topic [166]. In any case, some authors have attempted the reduction of the content of opium alkaloids in the seeds using different treatments. For example, while the levels of opium alkaloids were not affected by baking or steam application, a high reduction of these compounds can be obtained by water washing or extended thermal treatment [56].

In another context, immunoglobulin E-mediated sensitization to poppy seeds is rare, but if it occurs, the clinical symptoms can be severe, e.g., due to cross-sensitizations events $[167,168]$.

Concerning other Papaver species, some case studies in humans suggest that unconscious ingestion of $P$. rhoeas can cause acute liver toxicity [169] and intoxication with different effects (nausea, restlessness, dyspnoea, contractions unconsciousness, numbness, etc.) [170]. Alternatively, an in vivo study performed by Soulimani and coworkers [71] suggests that extracts from $P$. rhoeas petals (without the presence of alkaloids) showed a lethal dose $\left(\mathrm{LD}_{50}\right)$ of $4000 \mathrm{mg} / \mathrm{kg}$ and thus very low toxicity. However, sedative effects were observed. A study in vitro showed that $P$. rhoeas leaf extract also showed promising antimutagen/anticlastogen activity [171] and thus suggesting low toxicity. Therefore, although Papaver extracts can have some beneficial effects, toxicity studies are further required to establish dosage and side effects. Nonetheless, the culinary use of some parts and Papaver plants indicates that the safety issues are controversial or the dosage is a prerequisite. This includes $P$. somniferum seeds, with the aforementioned exceptions $[56,165]$; the shoots of $P$. rhoeas, the aerial parts of this species, and Papaver strictum Boiss. \& Balansa are added to salads, minestra, etc. [32, 35, 172]. Additionally, in Turkey, poppy flowers are used as food colorant and for enhancing the flavour of herbal teas [64].

\section{Clinical Trials}

Besides the aforementioned case reports studies, there are a very limited number of clinical studies reporting the health 
beneficial effects of Papaver plants, as far as we know. One of them tested the iodized poppy-seed oil as vehicle of the drug epirubicin against hepatocellular carcinoma $[173,174]$, but the anticancer effects of poppy have not been evidenced in humans. In the ClinicalTrials.gov database, there are two studies based on the administration of California poppy (Eschscholzia californica Cham.) (NCT03364101) but only one refers to the Papaver genus. In this work, ground poppy seeds were baked into a bran muffin and administered to evaluate the effect on postprandial blood glucose response, vascular, appetite, and sensory parameters (NCT01579656), but the results have still not been posted. Furthermore, a recent study on $P$. rhoeas combined with other herbs in syrup has improved sexual experience of men following consumption of this mixture with no drug-related serious adverse events. Therefore, the authors suggest that this aphrodisiac syrup can be applied alternatively to other chemical sexual drive enhancers with complicated side effects [175].

\section{Conclusions and Future Perspectives}

Besides the pharmacological interest of $P$. somniferum, the traditional use of different Papaver plants is widely established in different cultures and countries. This fact makes this genus attractive as a source of pharmacoactive extracts and compounds (alkaloids, phenolic compounds, and essential oil). These compounds are responsible for the multifaceted biological activities of the Papaver genus including anticancer, antioxidant, antimicrobial, and analgesic. The finding from different studies also demonstrated that these useful compounds are present throughout the plant including agro-residue generated from the Papaver plants. Nonetheless, pharmacological studies on extracts from these plants should be reinforced with characterization studies to know the active molecules, or if synergism exists that makes more interesting the use of the whole extracts. For that, bioassay-guided fractionation or even chemometrics with MS-based methodologies and HPLC with MS/MS can be applied to identify the overall profile of the Papaver plant extracts. This is especially important since the phytochemical composition and content as well as the bioactivity depend on several factors, including the genotype, the growth stage, and even the color of the flower. The phytochemical profile also depends on the method of extraction, input factors used for the extraction, and also on the style of preparation of the sample for analysis. Moreover, little is known about the bioactivity of the essential oil from these plants, even though some authors suggest the presence of phytol. This compound is valuable as a fragrance and exhibits a broad range of bioactivities [80].

Moreover, applications of this genus in nanotechnology seem promising, for example, to synthesize nanoparticles for different pharmacological purposes but further work is required, including more toxicity studies. In this sense, the use of plant extracts is increasing in green synthesis and the type of compounds present on these extracts can modulate the nanoparticle shape (Vijayaraghavan et al., [176]) and probably its functionality. Finally, although some preclinical results are promising, more clinical studies are needed to provide scientific evidence of the traditional use of Papaver plants before consumption and to avoid intoxication events. Overall, these studies along with a better known of the active molecules through comprehensive characterization and bioguided fractionation studies should be undertaken in future research.

\section{Abbreviations}

EFSA: European Food Safety Authority

$\mathrm{IC}_{50}$ : Inhibitory concentration at $50 \%$

$\mathrm{EC}_{50}$ : Half-maximal effective concentration

$\mathrm{LC}_{50}$ : Lethal concentration $50 \%$

MIC: Minimum inhibitory concentration

MS: Mass spectrometry

ZOI: Zone of inhibition.

\section{Conflicts of Interest}

The authors declare that they have no conflicts of interest.

\section{Acknowledgments}

Some of the components in Figure 2 are made with the help of icons by Freepik from Flaticon. M.d.M. Contreras would like to express their gratitude to the FEDER UJA project 1260905 funded by "Programa Operativo FEDER 20142020" and "Consejería de Economía y Conocimiento de la Junta de Andalucía" and the Ministry of Science and Innovation of Spain for the Ramón y Cajal grant (RYC2018026177-I/AEI/10.13039/501100011033).

\section{References}

[1] F. Labanca, J. Ovesnà, and L. Milella, "Papaver somniferum L. taxonomy, uses and new insight in poppy alkaloid pathways," Phytochemistry Reviews, vol. 17, pp. 853-871, 2018.

[2] J. Zhou, Y. Cui, X. Chen et al., "Complete chloroplast genomes of Papaver rhoeas and Papaver orientale: molecular structures, comparative analysis, and phylogenetic analysis," Molecules, vol. 23, no. 2, p. 437, 2018.

[3] D. J. Mabberley, Mabberley's Plant-Book, Cambridge University Press, Cambridge, 3th ed edition, 2008.

[4] S. Golmohammadzadeh, F. Zaefarian, and M. Rezvani, "Priming techniques, germination and seedling emergence in two Papaver species (P. rhoeas L. and P. dubium L., Papaveraceae)," Brazilian Journal of Botany, vol. 43, pp. 503-512, 2020.

[5] X. Liu, Y. Tian, C. Yuan, F. Zhang, and G. Yang, "Opium poppy detection using deep learning," Remote Sensing, vol. 10, p. 1886, 2018.

[6] United Nations, "Economic and Social Council," 2021, https://undocs.org/pdf?symbol=en/E/CN.7/2021/5.

[7] D. S. Kocabaş, M. Köle, and S. Yağc1, "Development and optimization of hemicellulose extraction bioprocess from poppy (Papaver somniferum L.) stalks assisted by instant controlled pressure drop (DIC) pretreatment," Biocatalysis and Agricultural Biotechnology, vol. 29, article 101793, 2020.

[8] FAOSTAT, 2021, https://www.fao.org/faostat/es/\#data/QC. 
[9] M. Hadipour, S. K. Kazemitabar, H. Yaghini, and S. Dayani, "Genetic diversity and species differentiation of medicinal plant Persian poppy (Papaver bracteatum L.) using AFLP and ISSR markers," Ecological Genetics and Genomics, vol. 16, article 100058, 2020.

[10] J. Torra and J. Recasens, "Demography of corn poppy (Papaver rhoeas) in relation to emergence time and crop competition," Weed Science, vol. 56, pp. 826-833, 2008.

[11] P. Razaghi and D. Zafari, "Characterization of fungi causing lesion blight on Papaver dubium in Iran," Antonie Van Leeuwenhoek, vol. 111, pp. 437-455, 2018.

[12] H. W. Lack, "The discovery and naming of Papaver orientale s.l. (Papaveraceae) with notes on its nomenclature and early cultivation," Candollea, vol. 74, no. 1, pp. 47-64, 2019.

[13] A. S. Choudhari, P. C. Mandave, M. Deshpande, P. Ranjekar, and O. Prakash, "Phytochemicals in cancer treatment: from preclinical studies to clinical practice," Frontiers in Pharmacology, vol. 10, p. 1614, 2020.

[14] T. T. Dang, A. Onoyovwi, S. C. Farrow, and P. J. Facchini, "Biochemical genomics for gene discovery in benzylisoquinoline alkaloid biosynthesis in opium poppy and related species," Methods in enzymology, vol. 515, pp. 231-266, 2012.

[15] P. B. Murphy, S. Bechmann, and M. J. Barrett, Morphine, StatPearls, 2021.

[16] N. Zare, R. Farjaminezhad, R. Asghari-Zakaria, and M. Farjaminezhad, "Enhanced thebaine production in Papaver bracteatum cell suspension culture by combination of elicitation and precursor feeding," Natural Product Research, vol. 28, pp. 711-717, 2014.

[17] United Nations, “Office on Drugs and Crime," 2020, https:// www.unodc.org/unodc/en/data-and-analysis/bulletin/ bulletin_1953-01-01_3_page005.html.

[18] EFSA, "EFSA, Opium alkaloids in poppy seeds:," 2019, https://www.efsa.europa.eu/en/press/news/180516.

[19] M. Singh, N. Chaturvedi, A. K. Shasany, and A. K. Shukla, "Impact of promising genotypes of Papaver somniferum L. developed for beneficial uses," Acta Horticulturae, vol. 1036, no. 1036, pp. 29-41, 2014.

[20] S. Selen Isbilir and A. Sagiroglu, “An assessment of In Vitro Antioxidant activities of different extracts from Papaver rhoeas L. leaves," International Journal of Food Properties, vol. 15, no. 6, pp. 1300-1308, 2012.

[21] U. Nyman and J. G. Bruhn, "Papaver bracteatum-a summary of current knowledge,” Planta Medica, vol. 35, no. 2, pp. 97117, 1979.

[22] J. B. Calixto, M. M. Campos, and A. R. S. Santos, "Botanical analgesic and anti-inflammatory drugs," in Ethnopharmacology, vol. II, Eolss Publishers, Oxford UK.

[23] F. Naghibi, S. Esmaeili, M. Malekmohammadi, A. Hassanpour, and M. Mosaddegh, "Ethnobotanical survey of medicinal plants used traditionally in two villages of Hamedan, Iran," Research Journal of Pharmacognosy, vol. 1, pp. 7-14, 2014.

[24] A. E. Farouji and H. Khodayari, "Ethnomedicinal plants of Farouj district, north khorasan province, Iran," Journal of Herbal Drugs (An International Journal on Medicinal Herbs), vol. 1, pp. 31-36, 2016.

[25] E. Altundaga and M. Ozturkb, "Ethnomedicinal studies on the plant resources of east Anatolia, Turkey," Procedia Social and Behavioral Sciences: The 2nd International Geography
Symposium GEOMED2010, vol. 19, 2011, pp. 756-777, East Anatolia; Turkey, 2011.

[26] U. Çakılcıoğlu, M. T. Şengün, and D. Türkoğlu, “An ethnobotanical survey of medicinal plants of Yazıkonak and Yurtbaşı districts of Elazı̆g province, Turkey," Journal of Medicinal Plants Research, vol. 4, pp. 567-572, 2010.

[27] S. Akbulut and M. M. Bayramoglu, "The trade and use of some medical and aromatic herbs in Turkey," Studies on Ethno-Medicine, vol. 7, pp. 67-77, 2013.

[28] R. Polat and F. Sat1l, "An ethnobotanical survey of medicinal plants in Edremit gulf (Balıkesir-Turkey)," Journal of Ethnopharmacology, vol. 139, pp. 626-641, 2012.

[29] I. Ugulu, "Traditional ethnobotanical knowledge about medicinal plants used for external therapies in Alasehir, Turkey," International Journal of Medicinal and Aromatic Plants, vol. 1, pp. 101-106, 2011.

[30] M. Yipel, F. A. Yipel, I. O. Tekeli, and Y. Guzel, "Ethnoveterinary uses of medicinal plants in Mediterranean district, Turkey," Revista de Chimie -Bucharest, vol. 68, no. 2, pp. 411416, 2017.

[31] M. R. González-Tejero, M. Casares-Porcel, C. P. SánchezRojas et al., "Medicinal plants in the Mediterranean area: synthesis of the results of the project Rubia," Journal of Ethnopharmacology, vol. 116, no. 2, pp. 341-357, 2008.

[32] G. Mattalia, C. L. Quave, and A. Pieroni, "Traditional uses of wild food and medicinal plants among Brigasc, Kyé, and Provençal communities on the Western Italian Alps," Genetic Resources and Crop Evolution, vol. 60, pp. 587-603, 2013.

[33] A. Pieroni, "Medicinal plants and food medicines in the folk traditions of the upper Lucca Province, Italy," Journal of Ethnopharmacology, vol. 70, pp. 235-273, 2000.

[34] A. Pieroni and C. L. Quave, "Traditional pharmacopoeias and medicines among Albanians and Italians in southern Italy: a comparison," Journal of Ethnopharmacology, vol. 101, pp. 258-270, 2005.

[35] A. M. Scherrer, R. Motti, and C. S. Weckerle, "Traditional plant use in the areas of Monte Vesole and Ascea, Cilento National Park (Campania, southern Italy)," Journal of Ethnopharmacology, vol. 97, pp. 129-143, 2005.

[36] S. Vitalini, F. Tomè, and G. Fico, "Traditional uses of medicinal plants in Valvestino (Italy)," Journal of Ethnopharmacology, vol. 121, no. 1, pp. 106-116, 2009.

[37] M. Bahmani, A. Zargaran, M. Rafieian-Kopaei, and K. Saki, "Ethnobotanical study of medicinal plants used in the management of diabetes mellitus in the Urmia, Northwest Iran," Asian Pacific Journal of Tropical Medicine, vol. 7, pp. S348S354, 2014.

[38] M. Nadaf, M. Joharchi, and M. S. Amari, "Ethnomedicinal uses of plants for the treatment of nervous disorders at the herbal markets of Bojnord, North Khorasan Province, Iran," Avicenna journal of phytomedicine, vol. 2, pp. 153-163, 2019.

[39] D. Jadnav, "Ethnomedical plants used by Bhil tribe of Bibdod, Madhya Pradesh," Indian Journal of Traditional Knowledge, vol. 5, pp. 263-267, 2006.

[40] P. A. Dar, N. Rashid, and A. Kalam, "Ethnomedicinal practices of Kashmir Valley: a review," Journal of Pharmacognosy and Phytochemistry, vol. 7, pp. 278-284, 2018.

[41] M. Goyal, "Use of ethnomedicinal plants for prophylaxis and management of postpartum complications among the Marwari community of Jodhpur District of Rajasthan," Food Quality and Safety, vol. 1, pp. 203-210, 2017. 
[42] S. K. Tayade and D. A. Patil, "Ethnomedicinal applications of spices and condiments in Nandurbar District (Maharashtra)," Journal of Ecobiotechnology, vol. 2, pp. 8-10, 2010.

[43] M. Adnan, I. Ullah, A. Tariq et al., "Ethnomedicine use in the war affected region of northwest Pakistan," Journal of Ethnobiology and Ethnomedicine, vol. 10, no. 1, p. 16, 2014.

[44] T. A. Alamgeer, M. Rashid, M. N. Malik, and M. N. Mushtaq, "Ethnomedicinal survey of plants of Valley Alladand Dehri, Tehsil Batkhela, District Malakand, Pakistan," International Journal of Basic Medical Sciences and Pharmacy, vol. 3, pp. 2049-4963, 2013.

[45] M. Irfan, M. K. Nabeela, N. A. Khan et al., "Ethnomedicinal and traditional knowledge of phanerogames of Tehsil Munda, district Lower Dir, Khyber Pakhtunkhwa, Pakistan," International Journal of Biosciences, vol. 4, pp. 208-218, 2018.

[46] S. Ullah, M. Rashid Khan, N. Ali Shah, S. Afzal Shah, M. Majid, and M. Asad Farooq, "Ethnomedicinal plant use value in the Lakki Marwat District of Pakistan," Journal of Ethnopharmacology, vol. 158, p. 412, 2014.

[47] H. Kim and M. J. Song, "Analyss of ethnomedical practices for treating skin diseases in communities on Jeju Island (Korea)," Indian Journal of Traditional Knowledge, vol. 13, pp. 673-680, 2014.

[48] B. Salehi, S. Vlaisavljevic, C. O. Adetunji et al., "Plants of the genus Vitis: Phenolic compounds, anticancer properties and clinical relevance," Trends in Food Science \& Technology, vol. 91, pp. 362-379, 2019.

[49] D. C. Hao, X.-J. Gu, and P. G. Xiao, "6- Phytochemical and biological research of Papaver pharmaceutical resources," Medicinal Plants, Chemisty, Biology and Omics, pp. 217251, 2015.

[50] V. Jablonická, J. Ziegler, Z. Vatehová et al., "Inhibition of phospholipases influences the metabolism of woundinduced benzylisoquinoline alkaloids in Papaver somniferum L," Journal of Plant Physiology, vol. 223, pp. 1-8, 2018.

[51] S. Choe, S. Kim, C. Lee et al., "Species identification of Papaver by metabolite profiling," Forensic Science International, vol. 211, no. 1-3, pp. 51-60, 2011.

[52] O. Bayazeid and F. N. Yalçın, "Biological targets of 92 alkaloids isolated from Papaver genus: a perspective based on in silico predictions," Medicinal Chemistry Research, vol. 30, pp. 574-585, 2021.

[53] G. Sariyar, "Biodiversity in the alkaloids of Turkish Papaver species," Pure and Applied Chemistry, vol. 74, no. 4, pp. 557-574, 2002.

[54] S. Frick, R. Kramell, J. Schmidt, A. J. Fist, and T. M. Kutchan, "Comparative qualitative and quantitative determination of alkaloids in narcotic and condiment Papaver somniferum cultivars," Journal of Natural Products, vol. 68, pp. 666-673, 2005.

[55] A. Gümüşçü, N. Arslan, and E. O. Sarihan, "Evaluation of selected poppy (Papaver somniferum L.) lines by their morphine and other alkaloids contents," European Food Research and Technology, vol. 226, pp. 1213-1220, 2008.

[56] S. A. Shetge, M. P. Dzakovich, J. L. Cooperstone, D. Kleinmeier, and B. W. Redan, "Concentrations of the opium alkaloids morphine, codeine, and thebaine in poppy seeds are reduced after thermal and washing treatments but are not affected when incorporated in a model baked product," Journal of Agricultural and Food Chemistry, vol. 68, pp. 5241-5248, 2020.
[57] J. Carolan, I. Hook, J. Walsh, and T. Hodkinson, "Using AFLP markers for species differentiation and assessment of genetic variability of in vitro-cultured Papaver bracteatum (section Oxytona)," In Vitro Cellular \& Developmental Biology, vol. 38, no. 3, pp. 300-307, 2002.

[58] T. Gürkök, E. Kaymak, G. Boztepe, M. Koyuncu, and I. Parmaksiz, "Molecular characterisation of the genus Papaver section Oxytona using ISSR markers," Turkish Journal of Botany, vol. 37, pp. 644-650, 2013.

[59] A. Qaderi, M. Omidi, A. Pour-Aboughadareh et al., "Molecular diversity and phytochemical variability in the Iranian poppy (_Papaver bracteatum__Lindl.): A baseline for conservation and utilization in future breeding programmes," Industrial Crops and Products, vol. 130, pp. 237-247, 2019.

[60] Y. N. Kalav and G. Sariyar, "Alkaloids from Turkish Papaver rhoeas,” Planta Medica, vol. 55, no. 5, p. 488, 1989.

[61] J.-P. Rey, J. Levesque, J.-L. Pousset, and F. Roblot, “Analytical studies of isorhoeadine and rhoeagenine in petal extracts of Papaver rhoeas L. using high-performance liquid chromatography," Journal of Chromatography A, vol. 596, pp. 276-280, 1992.

[62] M. Contreras, N. Bribi, A. M. Gómez-Caravaca, J. Gálvez, and A. Segura-Carretero, "Alkaloids Profiling of Fumaria capreolata by Analytical Platforms Based on the Hyphenation of Gas Chromatography and Liquid Chromatography with Quadrupole- Time-of-Flight Mass Spectrometry," International Journal of Analytical Chemistry, vol. 2017, Article ID 5178729, 16 pages, 2017.

[63] O. Bayazeid, C. C. Eylem, T. Reçber, F. N. Yalçın, S. Kır, and E. Nemutlu, "An LC-ESI-MS/MS method for the simultaneous determination of pronuciferine and roemerine in some Papaver species," Journal of Chromatography B, vol. 1096, pp. 223-227, 2018.

[64] I. Çoban, G. G. Toplan, B. Özbek, Ç. U. Gürer, and G. Sarıyar, "Variation of alkaloid contents and antimicrobial activities of Papaver rhoeas L. growing in Turkey and northern Cyprus," Pharmaceutical Biology, vol. 55, pp. 1894-1898, 2017.

[65] O. Bayazeid, Department of Pharmacognosy Phytochemical and pharmacological studies on some Papaver species in Turkey, Hacettepe University: Institute of Health Sciences, 2017.

[66] K. Song, J. H. Oh, S.-G. Lee, S. G. Lee, and I. J. Ha, "Molecular network-guided alkaloid profiling of aerial parts of Papaver nudicaule L. using LC-HRMS," Molecules, vol. 25, no. 11, p. 2636, 2020.

[67] Ç. Ünsal, G. Sarıyar, B. G. Akarsu, and A. Çevikbaş, “Antimicrobial activity and phytochemical studies on Turkish samples of Papaver macrostomum," Pharmaceutical Biology, vol. 45, no. 8, pp. 626-630, 2007.

[68] A. Mat, G. Sariyar, A. Deliorman, M. Atay, and N. Özhatay, "Alkaloids and bioactivity of Papaver dubium subsp. dubium and P. dubium subsp. laevigatum," Natural Product Letters, vol. 14, no. 3, pp. 205-210, 2000.

[69] HMDB, 2012, https://hmdb.ca/metabolites/HMDB0030169.

[70] D. A. Kostic, S. S. Mitic, M. N. Mitic et al., "Phenolic contents, antioxidant and antimicrobial activity of Papaver rhoeas L. extracts from Southeast Serbia," Journal of Medicinal Plants Research, vol. 4, no. 17, pp. 1727-1732, 2010.

[71] R. Soulimani, C. Younos, S. Jarmouni-Idrissi, D. Bousta, F. Khalouki, and A. Laila, "Behavioral and pharmacotoxicological study of Papaver rhoeas L. in mice," Journal of Ethnopharmacology, vol. 74, no. 3, pp. 265-274, 2001. 
[72] P. Hanelt, "Die Typisierung von Papaver nudicaule L. und die Einordnung vonP. nudicaule hort. non L," Die Kulturpflanze, vol. 18, no. 1, pp. 73-88, 1970.

[73] B. Dudek, A.-C. Warskulat, and B. Schneider, "The occurrence of flavonoids and related compounds in flower sections of Papaver nudicaule," Plants, vol. 5, no. 2, p. 28, 2016.

[74] E. C. Tatsis, H. Böhm, and B. Schneider, "Occurrence of nudicaulin structural variants in flowers of papaveraceous species," Phytochemistry, vol. 92, pp. 105-112, 2013.

[75] W. Schliemann, B. Schneider, V. Wray et al., "Flavonols and an indole alkaloid skeleton bearing identical acylated glycosidic groups from yellow petals of Papaver nudicaule," Phytochemistry, vol. 67, pp. 191-201, 2006.

[76] B. Kirkan, M. S. Özer, C. Sarikurkcu, M. Copuroglu, M. Cengiz, and B. Tepe, "Can the stalks of Papaver somniferum L. be an alternative source of bioactive components?," Industrial Crops and Products, vol. 115, pp. 1-5, 2018.

[77] M. Dilek, A. Gültepe, and N. Öztaşan, "Determination of Essential Oil Composition and Investigation of, Antimicrobial Properties of Poppy (Papaver Somniferum L.) Flower," AKU Journal of Science and Engineering, vol. 18, no. 3, pp. 786-795, 2018.

[78] S. Krist, G. Stuebiger, H. Unterweger, F. Bandion, and G. Buchbauer, "Analysis of volatile compounds and triglycerides of seed oils extracted from different poppy varieties (Papaver somniferum L.)," Journal of Agriculture and Food Chemistry, vol. 53, no. 21, pp. 8310-8316, 2005.

[79] G. Dogan and E. Bagcl, "Essential oil composition of Papaver rhoeas L. (corn poppy) (Papaveraceae) from Turkey," Hacettepe Journal of Biology and Chemistry, vol. 42, no. 4, pp. 545549, 2014.

[80] M. T. Islam, E. S. Ali, S. J. Uddin et al., "Phytol: a review of biomedical activities," Food and Chemical Toxicology, vol. 121, pp. 82-94, 2018.

[81] I. Stranska, M. Skalicky, J. Novak, E. Matyasova, and V. Hejnak, "Analysis of selected poppy (Papaver somniferum L.) cultivars: pharmaceutically important alkaloids," Industrial Crops and Products, vol. 41, pp. 120-126, 2013.

[82] I. N. Johnston and R. F. Westbrook, "Inhibition of morphine analgesia by LPS: role of opioid and NMDA receptors and spinal glia," Behavioural Brain Research, vol. 156, no. 1, pp. 75-83, 2005.

[83] M. Ibrar, M. Ehsan, U. Barkat, K. B. Marwat, and S. S. Mubarak, "Cytotoxic and of Papaver pavoninum Fisch \& Mey," Pakistan Journal of Botany, vol. 47, no. 5, pp. 18951899, 2015.

[84] J. Shams, H. Sahraei, Z. Faghih-Monzavi et al., "Effects of Papaver rhoeas extract on the tolerance development to analgesic effects of morphine in mice," Iranian Journal of Pharmaceutical Research, vol. 7, pp. 141-147, 2008.

[85] O. Bayazeid, E. Bedir, and F. N. Yalcin, "Ligand-based virtual screening and molecular docking of two cytotoxic compounds isolated from Papaver lacerum," Phytochemistry Letters, vol. 30, pp. 26-30, 2019.

[86] B. Dudek, F. Schnurrer, H.-M. Dahse et al., "Formation of nudicaulins in vivo and in vitro and the biomimetic synthesis and bioactivity of o-methylated nudicaulin derivatives," Molecules, vol. 23, no. 12, p. 3357, 2018.

[87] R. Demirgan, A. Karagöz, M. Pekmez et al., "In vitro anticancer activity and cytotoxicity of some papaver alkaloids on cancer and normal cell lines," African Journal of Traditional,
Complementary and Alternative Medicines, vol. 13, no. 3, pp. 22-26, 2016.

[88] D. A. Güler, A. Aydın, M. Koyuncu, İ. Parmaksız, and Ş. Tekin, "Anticancer activity of Papaver somniferum," Journal of the Turkish Chemical Society, Section A: Chemistry, vol. 3, no. 3, pp. 349-366, 2016.

[89] K. Hasplova, A. Hudecova, E. Miadokova et al., "Biological activity of plant extract isolated from Papaver rhoeas on human lymfoblastoid cell line," Neoplasma, vol. 58, no. 5, pp. 386-391, 2011.

[90] R. Ennamany, N. Leconte, J. Leclerc et al., "Sublethal UVB induces DNA lesions and pro-apoptotic gene transcription in human keratinocytes: attenuation by a mixture of plant extracts," Journal of Preventive Medicine, vol. 1, pp. 4-10, 2013.

[91] F. Khalighi-Sigaroodi, M. Ahvazi, A. Hadjiakhoondi et al., "Cytotoxicity and antioxidant activity of 23 plant species of Leguminosae family," Iranian Journal of Pharmaceutical Research, vol. 11, no. 1, pp. 295-302, 2012.

[92] P. Middleton, F. Stewart, S. Al-Qahtani et al., "Antioxidant, antibacterial activities and general toxicity of Alnus glutinosa, Fraxinus excelsior and Papaver rhoeas," Iranian Journal of Pharmaceutical Research, vol. 4, pp. 101-103, 2005.

[93] A. DeBono, B. Capuano, and P. J. Scammells, "Progress toward the development of noscapine and derivatives as anticancer agents," Journal of Medicinal Chemistry, vol. 58, pp. 5699-5727, 2015.

[94] M. A. Altinoz, G. Topcu, A. Hacimuftuoglu et al., "Noscapine, a non-addictive opioid and microtubule-inhibitor in potential treatment of glioblastoma," Neurochemical Research, vol. 44, no. 8, pp. 1796-1806, 2019.

[95] N. Maurya, J. K. Maurya, U. K. Singh et al., "In vitro cytotoxicity and interaction of noscapine with human serum albumin: effect on structure and esterase activity of HSA," Molecular Pharmaceutics, vol. 16, no. 3, pp. 952-966, 2019.

[96] L. T. P. Martin, M. W. Nachtigal, T. Selman et al., "Bitter taste receptors are expressed in human epithelial ovarian and prostate cancers cells and noscapine stimulation impacts cell survival," Molecular and Cellular Biochemistry, vol. 454, no. 1-2, pp. 203-214, 2019.

[97] A. Rabzia, M. Khazaei, Z. Rashidi, and M. R. Khazaei, “Synergistic anticancer effect of paclitaxel and noscapine on human prostate cancer cell lines," Iran Journal of Pharmaceutical Research, vol. 16, no. 4, pp. 1432-1442, 2017.

[98] X. Tian, M. Liu, Q. Zhu et al., "Down-regulation of liverintestine cadherin enhances noscapine-induced apoptosis in human colon cancer cells," Expert Review of Anticancer Therapy, vol. 17, no. 9, pp. 857-863, 2017.

[99] Z. Han, X. Huang, M. Liu et al., "Knock-down of cadherin 17 inhibits proliferation and promote apoptosis in noscapineresistant human SW480 colon cancer cells," Xi Bao Yu Fen Zi Mian Yi Xue Za Zhi, vol. 33, no. 5, pp. 606-610, 2017.

[100] M. He, L. Jiang, Z. Ren, G. Wang, and J. Wang, "Noscapine targets EGFR ${ }^{\text {p-Tyr1068 }}$ to suppress the proliferation and invasion of MG63 cells," Scientific Reports, vol. 6, no. 1, article 37062, 2016.

[101] H. Huang, L. J. Li, H. B. Zhang, and A. Y. Wei, "Papaverine selectively inhibits human prostate cancer cell (PC-3) growth by inducing mitochondrial mediated apoptosis, cell cycle arrest and downregulation of NF- $\kappa \mathrm{B} / \mathrm{PI} 3 \mathrm{~K} /$ Akt signalling pathway," Official journal of the Balkan Union of Oncology, vol. 22, no. 1, pp. 112-118, 2017. 
[102] W. Muhammad, M. A. Khan, M. Nazir et al., "Papaver somniferum L. mediated novel bioinspired lead oxide $(\mathrm{PbO})$ and iron oxide $\left(\mathrm{Fe}_{2} \mathrm{O}_{3}\right)$ nanoparticles: In- vitro biological applications, biocompatibility and their potential towards HepG2 cell line," Materials Science and Engineering: C, vol. 103, article 109740, 2019.

[103] E. S. Antonarakis, M. A. Carducci, and M. A. Eisenberger, "Novel targeted therapeutics for metastatic castrationresistant prostate cancer," Cancer Letters, vol. 291, pp. 1-13, 2010.

[104] S. K. Noureini and M. Wink, "Antiproliferative effect of the isoquinoline alkaloid papaverine in hepatocarcinoma HepG-2 Cells - Inhibition of telomerase and induction of senescence," Molecules, vol. 19, no. 8, pp. 11846-11859, 2014.

[105] S. Sajadian, M. Vatankhah, M. Majdzadeh, S. M. Kouhsari, M. H. Ghahremani, and S. N. Ostad, "Cell cycle arrest and apoptogenic properties of opium alkaloids noscapine and papaverine on breast cancer stem cells," Toxicology Mechanisms and Methods, vol. 25, no. 5, pp. 388-395, 2015.

[106] C. D. Arvanitis, G. B. Ferraro, and R. K. Jain, “The bloodbrain barrier and blood-tumour barrier in brain tumours and metastases," Nature Reviews Cancer, vol. 20, pp. 26-41, 2020.

[107] J. E. Wang, Y. H. Liu, L. B. Liu, C. Y. Xia, Z. Zhang, and Y. X. Xue, "Effects of combining low frequency ultrasound irradiation with papaverine on the permeability of the blood-tumor barrier," Journal of Neurooncology, vol. 102, no. 2, pp. 213224, 2011.

[108] M. Benej, X. Hong, S. Vibhute et al., "Papaverine and its derivatives radiosensitize solid tumors by inhibiting mitochondrial metabolism," Proceedings of National Academic Sciences, vol. 115, no. 42, pp. 10756-10761, 2018.

[109] M. Inada, M. Shindo, K. Kobayashi et al., "Anticancer effects of a non-narcotic opium alkaloid medicine, papaverine, in human glioblastoma cells," PLoS One, vol. 14, no. 5, article e0216358, 2019.

[110] S. Galadari, A. Rahman, S. Pallichankandy, and F. Thayyullathil, "Molecular targets and anticancer potential of sanguinarine-a benzophenanthridine alkaloid," Phytomedicine, vol. 34, pp. 143-153, 2017.

[111] S. Kumaravel and K. Alagusundaram, "Antimicrobial activity and phytochemical analysis of selected Indian spices," Journal of Pure and Applied Microbiology, vol. 8, no. 5, pp. 4131-4136, 2014.

[112] S. Dawar, S. Abbas, M. Tariq, and M. Zaki, "In vitro fungicidal activity of spices against root infecting fungi," Pakistan Journal of Botany, vol. 40, no. 1, pp. 433-438, 2008.

[113] Ç. Ünsal, B. Özbek, G. Sarıyar, and A. Mat, "Antimicrobial activity of four annual Papaver species growing in Turkey," Pharmaceutical Biology, vol. 47, no. 1, pp. 4-6, 2009.

[114] R. Istatkova, L. Nikolaeva-Glomb, A. Galabov et al., "Chemical and antiviral study on alkaloids from Papaver pseudocanescens M. Pop," Zeitschrift für Naturforschung C, vol. 67, no. 1-2, pp. 22-28, 2012.

[115] I.-K. Lee, B. S. Hwang, D.-W. Kim et al., "Characterization of neuraminidase inhibitors in Korean Papaver rhoeas bee pollen contributing to anti-influenza activities in vitro," Planta Medica, vol. 82, no. 6, pp. 524-529, 2016.

[116] M. Kačániová, J. Nóźková, K. Fatrcová-Šramková, Z. Kropková, and J. Kubincová, “Antioxidant, antimicrobial actiyity and heavy metals content in pollen of Papaver somni- ferum L," Ecological Chemistry and Engineering A, vol. 17, no. 1, pp. 97-106, 2010.

[117] B. Bazzaz and G. Haririzadeh, "Screening of Iranian plants for antimicrobial activity," Pharmaceutical Biology, vol. 41, no. 8, pp. 573-583, 2003.

[118] M. de, A. Krishna de, and A. Banerjee, "Antimicrobial screening of some Indian spices," Phytotherapy Research: An International Journal Devoted to Pharmacological and Toxicological Evaluation of Natural Product Derivatives, vol. 13, no. 7, pp. 616-618, 1999.

[119] S. Ishtiaque, S. Naz, R. Siddiqi, S. Jabeen, and J. Ahmed, "Antioxidant activity and phenolic contents of ajwain, mustard, fenugreek and poppy seed," Recent Innovations in Chemical Engineering, vol. 7, no. 2, pp. 119-127, 2014.

[120] Y. Zhang, G. Sun, Z. Hou, B. Yan, and J. Zhang, "Evaluation of the quality consistency of powdered poppy capsule extractive by an averagely linear quantified fingerprint method in combination with antioxidant activities and two compounds analyses," Journal of Separation Science, vol. 40, pp. 45114520, 2017.

[121] S. Baros, M. Karsayová, K. Jomová, A. Gáspár, and M. Valko, "Free radical scavenging capacity of Papaver somniferum L. and determination of pharmacologically active alkaloids using capillary electrophoresis," Journal of Microbiology, Biotechnology and Food Sciences, vol. 1, p. 725, 2012.

[122] F. Sharopov, A. Valiev, I. Gulmurodov, M. Sobeh, P. Satyal, and M. Wink, "Alkaloid content, antioxidant and cytotoxic activities of various parts of Papaver somniferum," Pharmaceutical Chemistry Journal, vol. 52, pp. 459-463, 2018.

[123] L. Aksoy, "Oxidant/antioxidant equilibrium in rats supplemented with diesel fuel or with opium poppy (Papaver somniferum L.) seed oil biodiesel," Revue de Médecine Vétérinaire, vol. 164, no. 1, pp. 34-38, 2013.

[124] M. Kazazic, M. Djapo, and E. Ademovic, "Antioxidant activity of water extracts of some medicinal plants from Herzegovina region," International Journal of Pure Applied and Biosciences, vol. 4, no. 2, pp. 85-90, 2016.

[125] T. Todorova, M. Pesheva, F. Gregan, and S. Chankova, “Antioxidant, antimutagenic, and anticarcinogenic effects of Papaver rhoeas L. extract on Saccharomyces cerevisiae," Journal of Medicinal Food, vol. 18, no. 4, pp. 460-467, 2015.

[126] A. Montefusco, G. Semitaio, P. P. Marrese et al., "Antioxidants in varieties of chicory (Cichorium intybus L.) and wild poppy (Papaver rhoeas L.) of southern Italy," Journal of Chemistry, vol. 2015, Article ID 923142, 8 pages, 2015.

[127] E. Krošlák, T. Maliar, P. Nemeček et al., "Antioxidant and proteinase inhibitory activities of selected poppy (Papaver somniferum L.) genotypes," Chemistry \& Biodiversity, vol. 14, no. 9, article e1700176, 2017.

[128] K. Alpinar, M. Özyürek, U. Kolak et al., "Antioxidant capacities of some food plants wildly grown in Ayvalik of Turkey," Food Science and Technology Research, vol. 15, no. 1, pp. 5964, 2009.

[129] E. Souri, G. Amin, and H. Farsam, "Screening of antioxidant activity and phenolic content of 24 medicinal plant extracts," DARU Journal of Pharmaceutical Sciences, vol. 16, no. 2, pp. 83-87, 2008.

[130] E. Souri, G. Amin, A. Dehmobed-Sharifabadi, A. Nazifi, and H. Farsam, "Antioxidative activity of sixty plants from Iran," Iranian Journal of Pharmaceutical Research, vol. 3, pp. 55-59, 2004. 
[131] S. Nehir El and S. Karakaya, "Radical scavenging and ironchelating activities of some greens used as traditional dishes in Mediterranean diet," International Journal of Food Sciences and Nutrition, vol. 55, no. 1, pp. 67-74, 2004.

[132] K. Koga, H. Shibata, K. Yoshino, and K. Nomoto, "Effects of $50 \%$ ethanol extract from rosemary (Rosmarinus officinalis) on ?-Glucosidase inhibitory activity and the elevation of plasma glucose level in rats, and its active compound," Journal of Food Science, vol. 71, no. 7, pp. S507-S512, 2006.

[133] B. Baharvand-Ahmadi, M. Bahmani, P. Tajeddini, N. Naghdi, and M. Rafieian-Kopaei, "An ethno-medicinal study of medicinal plants used for the treatment of diabetes," Journal of Nephropathology, vol. 5, no. 1, p. 44, 2016.

[134] A. Dalar, "Plant taxa used in the treatment of diabetes in Van Province, Turkey," International Journal of Secondary Metabolite, vol. 5, no. 3, pp. 171-185, 2018.

[135] H. N. Mrabti, N. Jaradat, M. R. Kachmar et al., "Integrative herbal treatments of diabetes in Beni Mellal region of Morocco," Journal of Integrative Medicine, vol. 17, no. 2, pp. 93-99, 2019.

[136] S. Ö. Sarikaya, H. Harput, and Ü. Şebnem, "Medicinal plants used for the treatment of diabetes in Turkey," Ankara Üniversitesi Eczacılık Fakültesi Dergisi, vol. 39, no. 4, pp. 317-342, 2010.

[137] H. A. M. Ahmed, S. M. Ahmed, E. El Gawish, A. M. Alanwar, and M. Ibrahem, "Effects of opium addiction on some biochemical parameters in diabetic rats," International Journal of Biochemistry Research \& Review, vol. 10, no. 3, pp. 1-6, 2016.

[138] S. Sadeghian, M. A. Boroumand, M. Sotoudeh-Anvari, S. Rabbani, M. Sheikhfathollahi, and A. Abbasi, "Effect of opium on glucose metabolism and lipid profiles in rats with streptozotocin-induced diabetes," Endokrynologia Polska, vol. 60 , no. 4, pp. 258-262, 2009.

[139] A. Golkar-Narenji, H. Eimani, F. Samadi et al., "Effect of Papaver rhoeas extract on in vitro maturation and developmental competence of immature mouse oocytes," Reproductive medicine and biology, vol. 9, no. 4, pp. 211-215, 2010.

[140] R. Rajabi-Toustani, R. Motamedi-Mojdehi, M. Roostaei-Ali Mehr, and R. Motamedi-Mojdehi, "Effect of Papaver rhoeas L. extract on in vitro maturation of sheep oocytes," Small Ruminant Research, vol. 114, no. 1, pp. 146-151, 2013.

[141] G. T. Mbemya, L. A. Vieira, F. G. Canafistula, O. D. L. Pessoa, and A. P. R. Rodrigues, "Relatos sobre a contribuiçao in vivo e in vitro de plantas medicinais na melhora da fun çao reprodutiva feminina," Reprodução \& Climatério, vol. 32, no. 2, pp. 109-119, 2017.

[142] T. A. Beck and B. A. Alford, Depression: Causes and Treatment, University of Pennsylvania Press, Pensilvania, USA, 2009.

[143] M. Ranjbaran, P. Mirzaei, F. Lotfi, S. Behzadi, and H. Sahraei, "Reduction of metabolic signs of acute stress in male mice by Papaver rhoaes hydro-alcoholic extract," Pakistan Journal of Bological Sciences, vol. 16, no. 19, pp. 1016-1021, 2013.

[144] P. Mirzaei, F. Lotfi Kashani, S. Behzadi, and H. Sahraei, “The effect of Papaver rhoeas distillate on learning, memory, corticosterone and anorexia in little laboratory mice under inescapable tension," Medical Science Journal of Islamic Azad Univesity-Tehran Medical Branch, vol. 23, pp. 21-29, 2013.

[145] N. Osanloo, A. Najafi-Abedi, F. Jafari et al., "Papaver rhoeas L. hydroalcoholic extract exacerbates forced swimming test- induced depression in mice," Basic and Clinical Neuroscience, vol. 7, no. 3, pp. 195-202, 2016.

[146] I. Gürbüz, O. Üstün, E. Yesilada, E. Sezik, and O. Kutsal, "Anti-ulcerogenic activity of some plants used as folk remedy in Turkey," Journal of Ethnopharmacology, vol. 88, no. 1, pp. 93-97, 2003.

[147] J.-H. Oh, M. Yun, D. Park et al., "Papaver nudicaule (Iceland poppy) alleviates lipopolysaccharide-induced inflammation through inactivating NF- $\kappa \mathrm{B}$ and STAT3," BMC Complementary and Alternative Medicine, vol. 19, no. 1, p. 90, 2019.

[148] M. J. Millan, "The induction of pain: an integrative review," Progress in Neurobiology, vol. 57, pp. 1-164, 1999.

[149] WHO, 2019, https://link.springer.com/article/10.1007/ s11060-010-0321-7.

[150] H. Pathan and J. Williams, "Basic opioid pharmacology: an update," British Journal of Pain, vol. 6, pp. 11-16, 2012.

[151] N. Bliesener, S. Albrecht, A. Schwager, K. Weckbecker, D. Lichtermann, and D. Klingmüller, "Plasma testosterone and sexual function in men receiving buprenorphine maintenance for opioid dependence," The Journal of Clinical Endocrinology and Metabolism, vol. 90, no. 1, pp. 203-206, 2005.

[152] S. Mercadante, "Pathophysiology and treatment of opioidrelated myoclonus in cancer patients," Pain, vol. 74, no. 1, pp. 5-9, 1998.

[153] S. Takeda, L. I. Eriksson, Y. Yamamoto, H. Joensen, H. Onimaru, and S. G. E. Lindahl, "Opioid action on respiratory neuron activity of the isolated respiratory network in newborn rats," Anesthesiology, vol. 95, no. 3, pp. 740-749, 2001.

[154] A. Rumman, Z. R. Gallinger, and L. W. C. Liu, "Opioid induced constipation in cancer patients: pathophysiology, diagnosis and treatment," Journal of Expert Review of Quality of Life in Cancer Care, vol. 1, no. 1, pp. 25-35, 2016.

[155] C. Kohberg, C. U. Andersen, and E. Bendstrup, "Opioids: an unexplored option for treatment of dyspnea in IPF," European Clinical Respiratory Journal, vol. 3, article 30629, 2016.

[156] G. M. Rocker, A. C. Simpson, Joanne Young BHSc et al., "Opioid therapy for refractory dyspnea in patients with advanced chronic obstructive pulmonary disease: patients' experiences and outcomes," CMAJ Open, vol. 1, no. 1, pp. E27-E36, 2013.

[157] EFSA, 2018, https://www.efsa.europa.eu/en/press/news/ 180516.

[158] L. A. Colvin, F. Bull, and T. G. Hales, "Perioperative opioid analgesia-when is enough too much? A review of opioidinduced tolerance and hyperalgesia," Postoperative pain Management and Opioids, vol. 393, no. 10180, pp. 15581568, 2019.

[159] B. Gyawali, N. Hayashi, H. Tsukuura, K. Honda, T. Shimokata, and Y. Ando, "Opioid-induced constipation," Scandinavian Journal of Gastroenterology, vol. 50, pp. 13311338, 2015.

[160] T. Jitpakdee and S. Mandee, "Strategies for preventing side effects of systemic opioid in postoperative pediatric patients," Pediatric Anesthesia, vol. 24, pp. 561-568, 2014.

[161] J. L. Martin, L. Koodie, A. G. Krishnan, R. Charboneau, R. A. Barke, and S. Roy, "Chronic morphine administration delays wound healing by inhibiting immune cell recruitment to the wound site," The American Journal of Pathology, vol. 176, no. 2, pp. 786-799, 2010. 
[162] P. O. Anderson, A. S. Manoguerra, and V. Valdes, "A review of adverse reactions in infants from medications in breastmilk," Clinical Pediatrics, vol. 55, pp. 236-244, 2016.

[163] P. Madadi, C. J. Ross, M. R. Hayden et al., "Pharmacogenetics of neonatal opioid toxicity following maternal use of codeine during breastfeeding: a case-control study," Clinical Pharmacology and Therapeutics, vol. 85, no. 1, pp. 31-35, 2009.

[164] J. Lainer, C. Dawid, A. Dunkel, P. Gläser, S. Wittl, and T. Hofmann, "Characterization of bitter-tasting oxylipins in poppy seeds (Papaver somniferum L.)," Journal of Agricultural and Food Chemistry, vol. 68, no. 38, pp. 10361-10373, 2020.

[165] L. M. Schuppener and R. F. Corliss, "Death due to complications of bowel obstruction following raw poppy seed ingestion," Journal of Forensic Sciences, vol. 63, no. 2, pp. 614618, 2018.

[166] I. Haber, J. Pergolizzi Jr., and J. A. LeQuang, "Poppy seed tea: a short review and case study," Pain and therapy, vol. 8, no. 1, pp. 151-155, 2019.

[167] B. Frantzen, E. B. Bröcker, and A. Trautmann, "Immediatetype allergy caused by poppy seed," Allergy, vol. 55, no. 1, pp. 97-98, 2000.

[168] T. Oppel, P. Thomas, and A. Wollenberg, "Cross-sensitization between poppy seed and buckwheat in a food-allergic patient with poppy seed anaphylaxis," International Archives of Allergy and Immunology, vol. 140, no. 2, pp. 170-173, 2006.

[169] Y. K. Günaydın, Z. D. Dündar, B. Çekmen, N. B. Akıllı, R. Köylü, and B. Cander, "Intoxication due to Papaver rhoeas (corn poppy): five case reports," Case Reports in Medicine, vol. 2015, Article ID 321360, 3 pages, 2015.

[170] H. Gonullu, S. Karadas, A. C. Dulger, and S. Ebinc, "Hepatotoxicity associated with the ingestion of Papaver rhoease," Journal of Pakistan Medical Association, vol. 64, pp. 11891190, 2014.

[171] S. Gateva, G. Jovtchev, A. Stankov, and F. Gregan, "Antigenotoxic capacity of Papaver rhoeas L. extract," International Journal of Pharmacy and Pharmaceutical Sciences, vol. 6, no. 1, pp. 717-723, 2014.

[172] M. Kargığlu, S. Cenkci, A. Serteser, M. Konuk, and G. Vural, "Traditional uses of wild plants in the middle Aegean region of Turkey," Human Ecology, vol. 38, pp. 429-450, 2010.

[173] S. Higashi and T. Setoguchi, "Hepatic arterial injection chemotherapy for hepatocellular carcinoma with epirubicin aqueous solution as numerous vesicles in iodinated poppyseed oil microdroplets: clinical application of water-in-oilin-water emulsion prepared using a membrane emulsification technique," Advanced Drug Delivery Reviews, vol. 45, pp. 57-64, 2000.

[174] S. Higashi, M. Shimizu, T. Nakashima et al., "Arterial-injection chemotherapy for hepatocellular carcinoma using monodispersed poppy-seed oil microdroplets containing fine aqueous vesicles of Epirubicin initial medical application of a membrane-emulsification technique," Cancer, vol. 75, no. 6 , pp. 1245-1254, 1995.

[175] N. Ebrahimpour, M. Khazaneha, M. Mehrbani, P. Rayegan, and M. Raeiszadeh, "Efficacy of herbal based syrup on male sexual experiences: a double-blind randomized clinical trial," Journal of Traditional and Complementary Medicine, vol. 11, pp. 103-108, 2021.

[176] K. Vijayaraghavan, S. P. K. Nalini, N. U. Prakash, and D. Madhankumar, "One step green synthesis of silver nano/ microparticles using extracts of Trachyspermum ammi and Papaver somniferum," Colloids and Surfaces B: Biointerfaces, vol. 94, pp. 114-117, 2012.

[177] M. Heydari, M. H. Hashempur, and A. Zargaran, "Medicinal aspects of opium as described in Avicenna's canon of medicine," Acta Medico-Historica Adriatica, vol. 11, no. 1, pp. 101-112, 2013.

[178] M. A. Hijazi, M. Aboul-Ela, K. Bouhadir et al., "Cytotoxic activity of alkaloids from Papaver rhoeas growing in Lebanon," Records of Natural Products, vol. 11, no. 2, p. 211, 2017.

[179] M. A. Hijazi, E. El-Mallah, M. Aboul-Ela, and A. Ellakany, "Evaluation of analgesic activity of Papaver libanoticum extract in mice: involvement of opioids receptors," Evidence-based Complementary and Alternative Medicine, vol. 2017, Article ID 8935085, 2017.

[180] J. Oh, Y. Shin, I. J. Ha et al., "Transcriptome profiling of two ornamental and medicinal papaver herbs," International Journal of Molecular Sciences, vol. 19, no. 10, p. 3192, 2018.

[181] J.-H. Oh, I.-J. Ha, M. Y. Lee et al., "Identification and metabolite profiling of alkaloids in aerial parts of Papaver rhoeas by liquid chromatography coupled with quadrupole time-offlight tandem mass spectrometry," Journal of Separation Science, vol. 41, no. 12, pp. 2517-2527, 2018. 